In cooperation with the Wisconsin Department of Natural Resources

\title{
Effects of Best-Management Practices in the Black Earth Creek Priority Watershed, Wisconsin, 1984-98
}

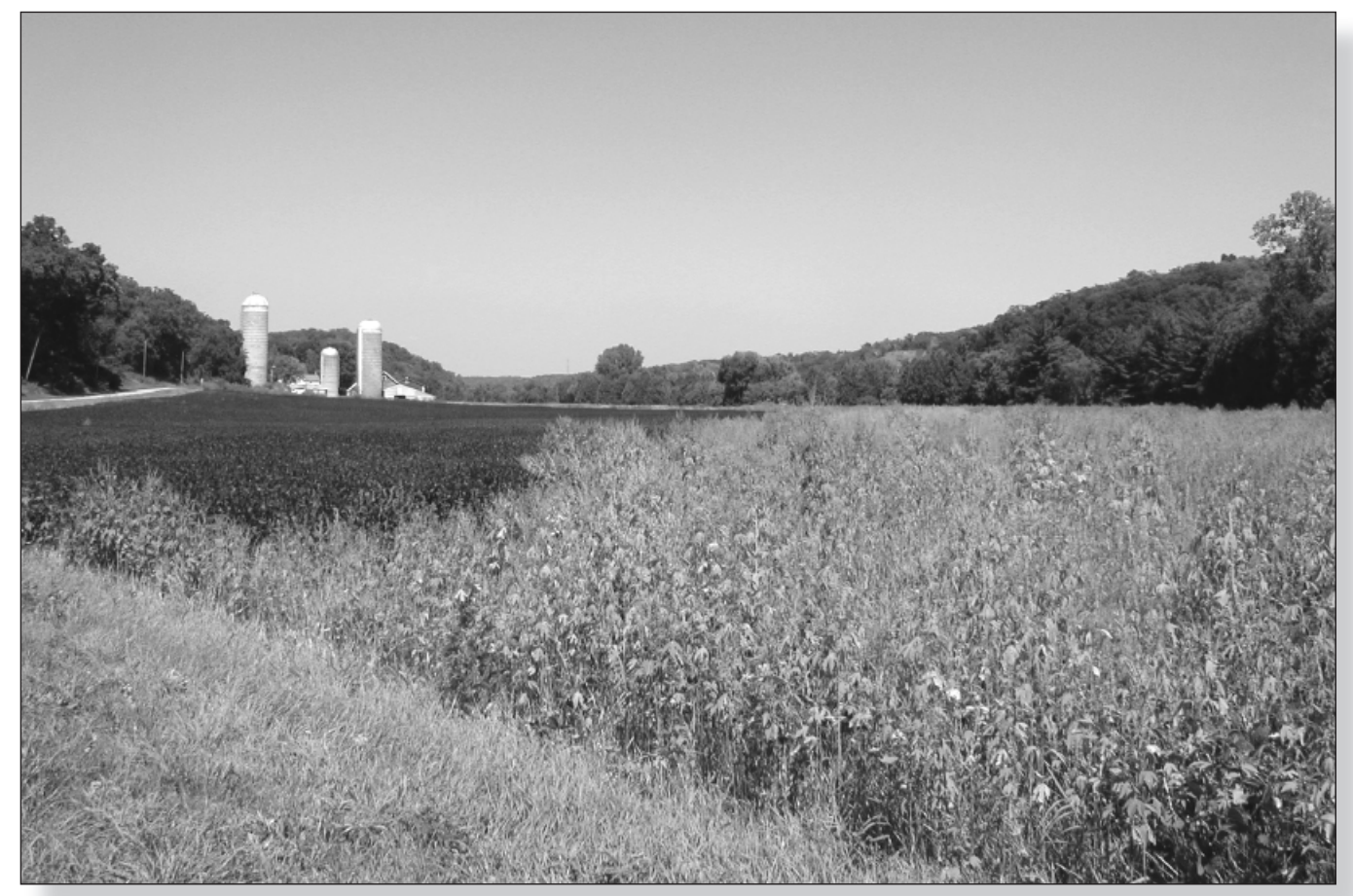

Water-Resources Investigations Report 03-4163 


\section{Effects of Best-Management Practices in the Black Earth Creek Priority Watershed, Wisconsin, 1984-98}

By D.J. Graczyk', J.F. Walker', J.A. Horwatich', and R.T. Bannerman²

In cooperation with the Wisconsin Department of Natural Resources

${ }^{1}$ U.S. Geological Survey, ${ }^{2}$ Wisconsin Department of Natural Resources

Water-Resources Investigations Report 03-4163 


\title{
U.S. Department of the Interior \\ Gale A. Norton, Secretary \\ U.S. Geological Survey \\ Charles G. Groat, Director
}

U.S. Geological Survey, Reston, Virginia: 2003

\author{
For sale by U.S. Geological Survey, Information Services \\ Box 25286, Denver Federal Center \\ Denver, CO 80225 \\ For more information about the USGS and its products: \\ Telephone: 1-888-ASK-USGS \\ World Wide Web: http://www.usgs.gov/
}

Any use of trade, product, or firm names in this publication is for descriptive purposes only and does not imply endorsement by the U.S. Government. 


\section{Contents}

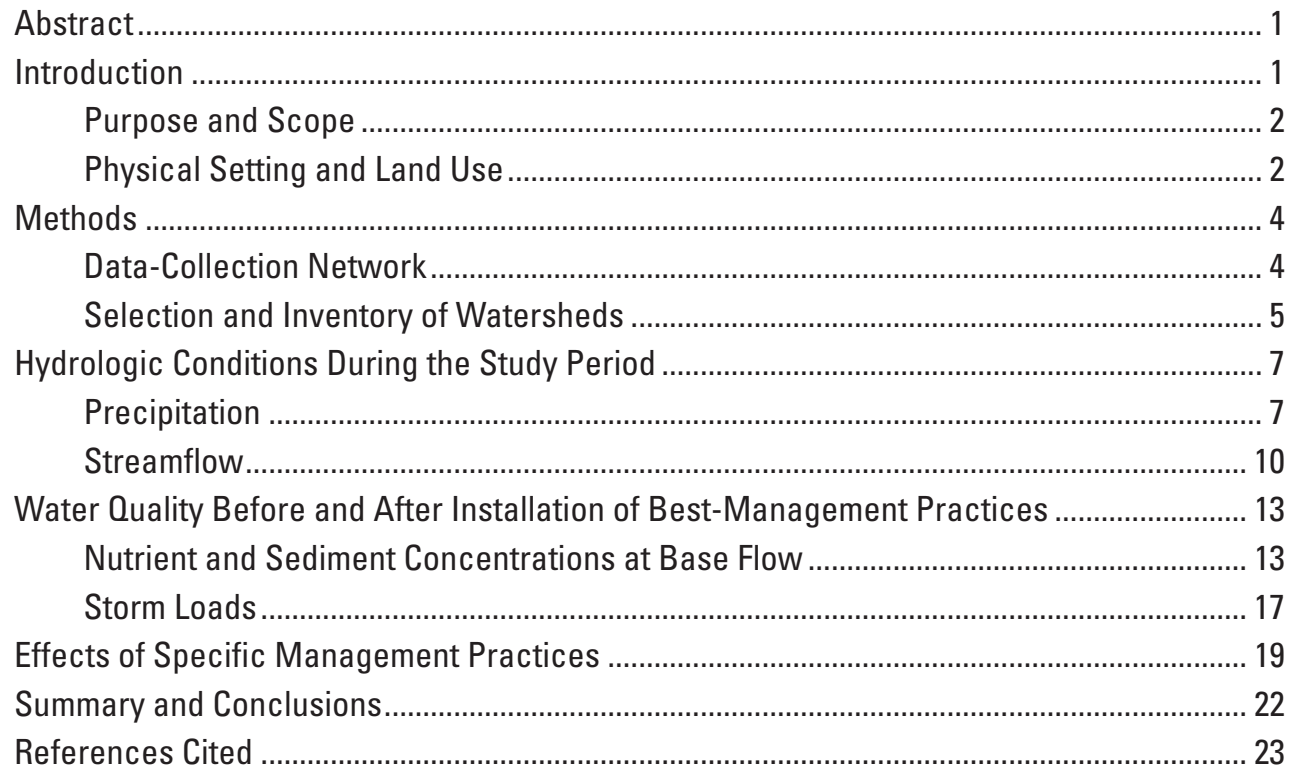

\section{Figures}

1. Map showing the location of the Black Earth Creek watershed in Dane County, Wis., and data-collection sites

2. Pie charts showing percentage of total land use and land cover for Brewery and Garfoot Creek watersheds, Dane County, Wis.

3. Map showing eligible and implemented best-management practices (BMPs), Brewery and Garfoot Creek watersheds, Dane County, Wis.

4-12. Graphs showing:

4. Yearly precipitation at Brewery and Garfoot Creeks and 1961-90 normal precipitation at Madison, Wis.

5. Histograms of precipitation events at Brewery Creek, Dane County, Wis., for which storm loads were calculated.

6. Histograms of precipitation events at Garfoot Creek, Dane County, Wis., for which storm loads were calculated

7. Streamflow characteristics for Brewery Creek, Dane County, Wis. ................. 10

8. Streamflow characteristics for Garfoot Creek, Dane County, Wis.................... 12

9. Streamflow characteristics for Black Earth Creek, Dane County, Wis............ 13

10. Annual streamflow and base flow with 3-year moving average for Black Earth Creek, Dane County, Wis., 1955-98 water years

11. Concentrations and water-year medians of suspended sediment and nutrients in base-flow samples during the data-collection period at Brewery Creek, Dane County, Wis.

12. Concentrations and water-year medians of suspended sediment and nutrients in base-flow samples during the data-collection period at Garfoot Creek, Dane County, Wis 


\section{Tables}

1. Summary of eligible and implemented rural best-management practices in the Brewery and Garfoot Creek watersheds, Wis.

2. Summary of streamflow characteristics for Brewery, Garfoot, and Black Earth Creeks, Wis., for pre-and post-BMP periods

3. Peak streamflow and selected recurrence intervals for Black Earth Creek,Wis., 1954-98

4. Results of the Kendall test of trend in streamflow characteristics, Black Earth Creek near Black Earth, Wis., water years 1954-98

5. Results of the Wilcoxon rank-sum test on the median concentrations of suspended sediments and nutrients at base flow, pre- and post-BMP periods, Brewery and Garfoot Creeks, Wis.

6. Regression results for storm loads at Brewery and Garfoot Creeks, Wis

7. Results of the Wilcoxon rank-sum test comparing storm loads and storm-load residuals for pre- and post-BMP periods at Brewery and Garfoot Creeks, Wis.

8. Matrix of interactions between BMPs and different aspects of water quality, with statistical test results from comparing pre-to post-BMP periods for a generalized watershed, at Brewery and Garfoot Creek watersheds, Wis. 


\section{Conversion Factors and Abbreviations}

\begin{tabular}{lcl}
\hline Multiply & By & To obtain \\
\hline \multicolumn{3}{c}{ Length } \\
\hline inch (in.) & 25.4 & millimeter $(\mathrm{mm})$ \\
foot (ft) & 0.3048 & meter $(\mathrm{m})$ \\
mile (mi) & 1.609 & kilometer $(\mathrm{km})$ \\
\hline \multicolumn{3}{c}{ Area } \\
\hline acre & 0.4047 & square hectometer $\left(\mathrm{hm}^{2}\right)$ \\
square mile $\left(\mathrm{mi}^{2}\right)$ & 2.590 & square kilometer $\left(\mathrm{km}^{2}\right)$ \\
\hline cubic foot per second $(\mathrm{ft} / \mathrm{s})$ & Flow rate & \\
\hline \multicolumn{3}{c}{0.02832} \\
\hline pound, avoirdupois $(\mathrm{lb})$ & Mass & cubic meter per second $\left(\mathrm{m}^{3} / \mathrm{s}\right)$ \\
\hline foot per mile $(\mathrm{ft} / \mathrm{mi})$ & 0.4536 & kilogram $(\mathrm{kg})$ \\
\hline
\end{tabular}

Temperature in degrees Celsius $\left({ }^{\circ} \mathrm{C}\right)$ may be converted to degrees Fahrenheit $\left({ }^{\circ} \mathrm{F}\right)$ as follows:

$$
{ }^{\circ} \mathrm{F}=\left(1.8 x^{\circ} \mathrm{C}\right)+32
$$

Abbreviated water-quality units used in this report: Chemical concentrations and water temperature are given in metric units. Chemical concentration is given in milligrams per liter $(\mathrm{mg} / \mathrm{L})$, micrograms per liter $(\mu \mathrm{g} / \mathrm{L})$. Milligrams per liter is a unit expressing the concentration of chemical constituents in solution as weight (milligrams) of solute per unit volume (liter) of water. One-thousand micrograms per liter is equivalent to 1 milligram per liter. For concentrations less than $7,000 \mathrm{mg} / \mathrm{L}$, the numerical value is the same as for concentrations in parts per million.

Water year: Water year in USGS reports dealing with surface-water supply is the 12-month period October 1 through September 30. The water year is designated by the calendar year in which it ends and includes 9 of the 12 months. Thus, the year ending September 30, 1998, is called the "1998 water year." 


\title{
Effects of Best-Management Practices in the Black Earth Creek Priority Watershed, Wisconsin, 1984-98
}

\author{
By D.J. Graczyk', J.F. Walker', J.A., Horwatich', and R.T. Bannerman²
}

\section{Abstract}

The Wisconsin Department of Natural Resources and the U.S. Geological Survey began a comprehensive, multidisciplinary evaluation-monitoring program in 1989 to assess the effectiveness of the Wisconsin Nonpoint Source Program. Hydrologic and water-quality data were collected at Brewery and Garfoot Creeks in 1984 and 1985 (pre-best-management practices (BMPs) period) and 1997 and 1998 (post-BMP period). In rural areas, best-management practices may include conservation tillage, contour strip-cropping, streambank protection, and various barnyard-runoff controls. Water-quality samples were collected during base flow and storms.

At Brewery Creek, no statistically significant differences in the median base flow water-quality concentrations between the pre- and post-BMP periods. At Garfoot Creek, the median suspended-sediment concentration at base flow decreased by 41 percent between the pre- and post-BMP periods and the median ammonia nitrogen concentration decreased by 67 percent. Both of these differences were statistically significant at the 0.05 (probability) level.

For both Brewery and Garfoot Creeks, the median storm loads for suspended sediment, total phosphorus, and ammonia nitrogen were compared statistically by means of the Wilcoxon rank-sum test. This test also was applied to regression residuals for differences between the preand post-BMP periods. For Garfoot Creek, only the median load for ammonia nitrogen shows a statistically significant difference between the pre-and post-BMP periods. None of the median storm loads for Brewery Creek were statistically significant at the 0.05 level. The decrease of the regression residuals between the pre- and post-BMP periods for ammonia nitrogen at Brewery Creek and for total phosphorus and ammonia nitrogen at Garfoot Creek all were statistically significant at the 0.05 level. These reductions between the pre- and post-BMP periods likely are results of the installed BMPs.

The effectiveness of the BMPs on water quality are watershed specific. The effectiveness of the practice will depend on the type, number, and location of the BMPs implemented.

\section{Introduction}

Nonpoint-source contamination is a major contributor to water-quality problems in many watersheds. In recognition of the importance of nonpoint sources, the Wisconsin Nonpoint Source Water Pollution Abatement Program (Nonpoint Program) was enacted in 1978. When first introduced, the Nonpoint Program identified problems in 130 of the 330 watersheds in Wisconsin. For a given watershed, various management options-termed bestmanagement practices (BMPs) - are available for funding support through the Nonpoint Program. For example, practices in rural areas include conservation tillage, contour strip-cropping, streambank protection, and various barnyard-runoff controls. Using priority watersheds as a unit for consideration, the Nonpoint Program provides matching funds to landowners for voluntary implementation of various BMPs.

The U.S. Geological Survey (USGS), in cooperation with the Wisconsin Department of Natural Resources (WDNR), studied the Black Earth Creek watershed in southern Wisconsin from October 1984 through September 1986 to assess the hydrology, aquatic macrophytes, and water quality of Black Earth Creek and its tributaries. Streamflow and water-quality data were collected continuously at one site on a cold-water trout stream (Garfoot Creek near Cross Plains) and one site on a warm-water stream (Brewery Creek at Cross Plains). 
The information presented in a report from that study included determination of (1) streamflow, (2) aquatic macrophyte species and biomass, (3) suspended-sediment, total phosphorus, and total nitrogen loads, (4) miscellaneous water-quality characteristics, (5) water temperatures, and (6) concentrations of dissolved oxygen (Field and Graczyk, 1990). Data from that study were used to develop a plan for the control of nonpoint-source pollution and related resource management in the Black Earth Creek watershed (Wisconsin Department of Natural Resources, 1989).

By the mid-1980s, it was clear that little data were available to demonstrate the effectiveness of using BMPs to improve water quality in Wisconsin's priority watersheds. The WDNR and USGS developed and began a comprehensive, multidisciplinary evaluation-monitoring program in water year 1989 to assess the effectiveness of the Wisconsin Nonpoint Source Program (Wierl and others, 1996). This evaluation-monitoring program includes biological and stream-habitat monitoring by the WDNR and water-quality monitoring by USGS. Brewery and Garfoot Creeks were the first watersheds monitored for water quality. These watersheds were chosen because data prior to BMP implementation already were collected and BMPs were scheduled to be installed immediately after monitoring began.

\section{Purpose and Scope}

This report summarizes the results of a study on effectiveness of watershed-management practices for controlling nonpoint-source contamination in the Brewery and Garfoot Creek watersheds. Concentrations of phosphorus, nitrogen, and suspended sediment at base flow before BMP installation (pre-BMP) are compared and contrasted to those for the period after BMP installation (post-BMP). In addition, pre-BMP storm loads are compared and contrasted to the storm loads post-BMP.

During October 1984 through September 1986, no BMPs were installed in either watershed. Installation of BMPs began in 1989 and was completed in 2001. Data collection was reinitiated in October 1989 and continued until September 1998. In October 1996, sufficient BMPs were installed in each watershed to consider the subsequent period to be the post-implementation period. For Brewery Creek, the pre-BMP period is from October 1984 through September 1986. For Garfoot Creek, a sufficient number of pre-BMP storms had not been obtained prior to resumption of data collection; therefore, the pre-BMP period was extended and consists of October 1984 through April 1990. The post-BMP for Brewery Creek period is from October 1996 through September 1998 and for Garfoot Creek from April 1997 through September 1998.

\section{Physical Setting and Land Use}

Garfoot and Brewery Creeks, tributaries to Black Earth Creek, are in northwestern Dane County (fig. 1). Garfoot Creek has been classified by the WDNR as a class II trout stream; that is, a stream in which some natural trout reproduction occurs but artificial propagation is needed to maintain a trout fishery. Brewery Creek is a warm-water stream that has the potential to maintain a forage fish population (Wisconsin Department of Natural Resources, 1989).

Garfoot Creek drains $5.39 \mathrm{mi}^{2}$ upstream from the streamflow-gaging station near Cross Plains (fig. 1), and the stream channel is $3.9 \mathrm{mi}$ long from the station to the stream headwaters. The overall channel slope is $97 \mathrm{ft} / \mathrm{mi}$, and the channel slope between the 10- and 85-percent points of the main channel is $47 \mathrm{ft} / \mathrm{mi}$. The bed material consists mainly of sand, silt, and clay with gravel in riffle areas. Garfoot Creek flows along a wide valley floor flanked by steep valley walls. The valley floor of Garfoot Creek is mainly outwash and alluvium composed of sand, gravel, and clay (Cline, 1963). The valley walls are soilcovered sandstone, shale, and dolomite bedrock. The soils of Garfoot Creek are primarily silt loams; some of the silt loams are poorly drained, and water can pond in depressions (Glocker and Patzer, 1978.)

Brewery Creek drains $10.5 \mathrm{mi}^{2}$ upstream from the streamflow-gaging station near Cross Plains, which includes $2.82 \mathrm{mi}^{2}$ of noncontributing area. The stream channel is $6.1 \mathrm{mi}$ long from the station to the stream headwaters and has been channelized in some parts. The mainchannel slope is $40 \mathrm{ft} / \mathrm{mi}$, and the channel slope between the 10- and 85-percent points of the main channel is 35 $\mathrm{ft} / \mathrm{mi}$. The bed material of the stream channel is mostly soft silt and clay. Brewery Creek flows through outwash and alluvium composed of sandstone with some shale; most of the bedrock in the watershed is dolomite. The soils of the Brewery Creek watershed are silt loams that are poorly drained in valley bottoms and highly erodible in the uplands (Glocker and Patzer, 1978).

Total land use and land cover for Garfoot and Brewery Creeks are shown in figure 2. As of 1987, cropland and woodlot dominated the land use and land cover in the two watersheds. In the Brewery Creek watershed, cropland 


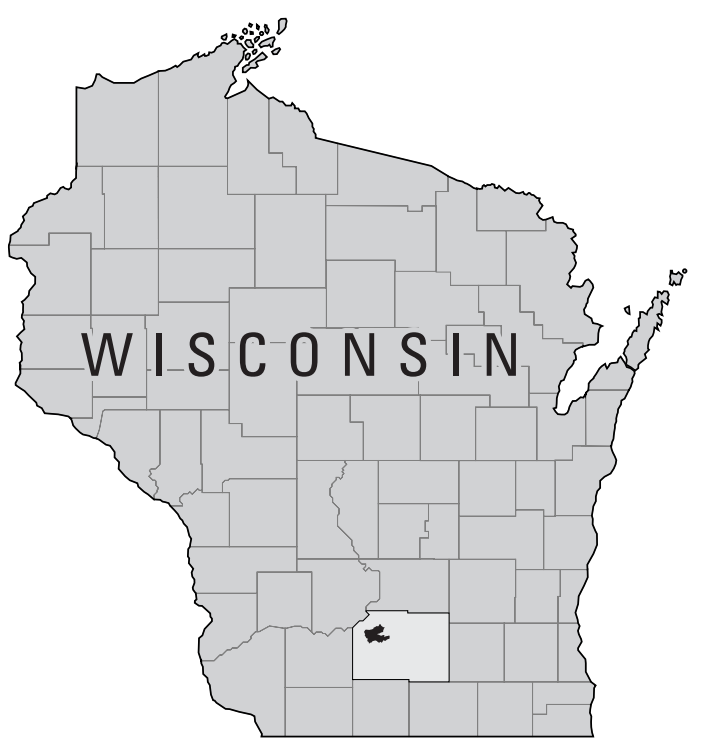

EXPLANATION

Watershed location in Dane County

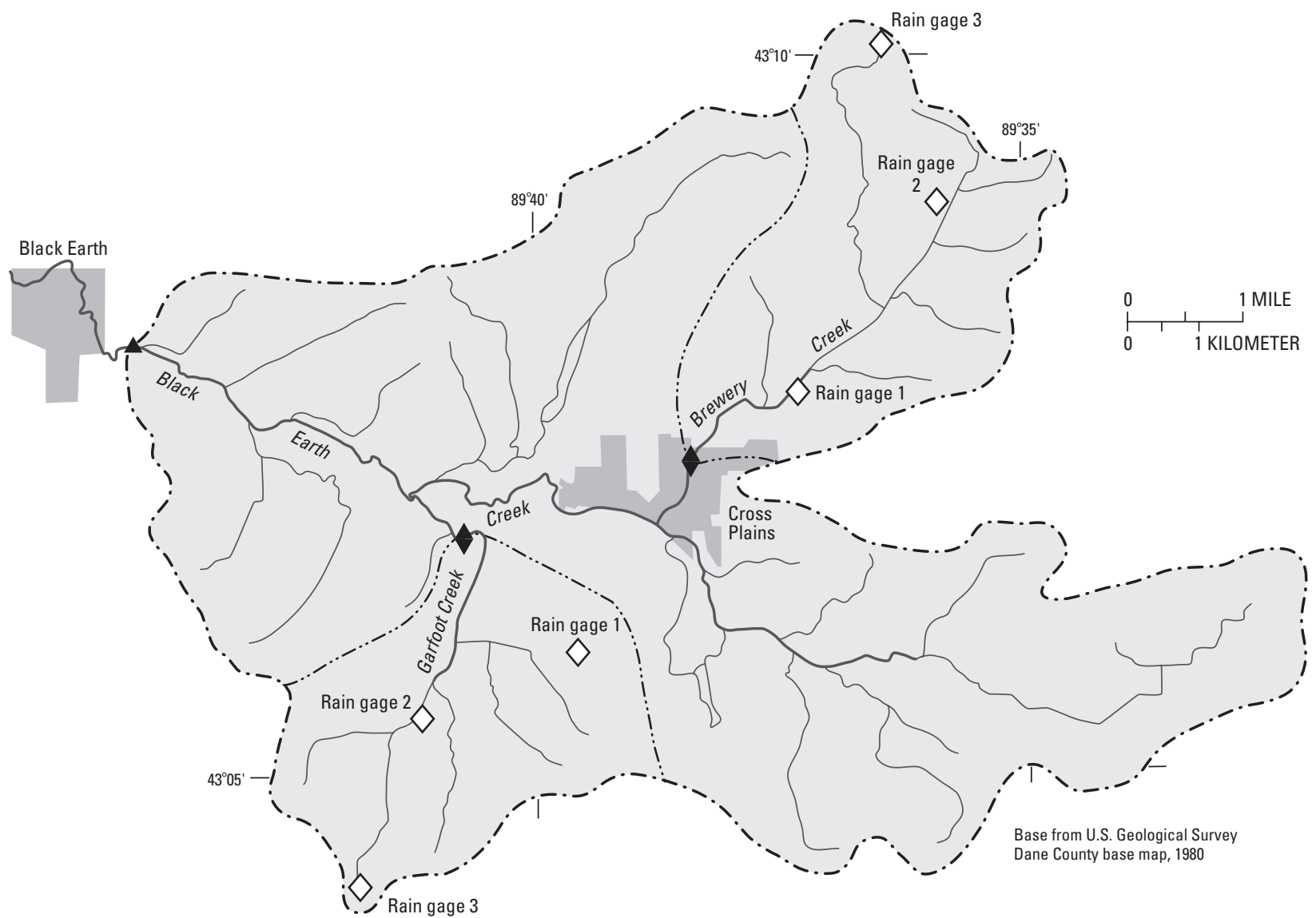

Figure 1. Location of the Black Earth Creek watershed in Dane County, Wis., and data-collection sites. 
(57 percent) was the dominant land use and land cover, with woodlot (22 percent) being the next greatest land use and land cover. In the Garfoot Creek watershed, woodlot (50 percent) dominated the land use and land cover, with cropland (26 percent) being the next greatest land use and land cover. Other land use and land cover in Brewery Creek included grassland (5 percent), pasture (4 percent), and residential ( 3 percent). The area just upstream from the data-collection site was a residential area. There was more pasture (10 percent) and grassland ( 8 percent) in the Garfoot Creek watershed than in the Brewery Creek watershed (4 and 5 percent, respectively). The area just upstream from the data-collection site at Brewery Creek was a residential area. Residential development in the Garfoot Creek watershed, which typically was singlefamily homes on large lots, was minimal.

\section{Methods}

\section{Data-Collection Network}

Streamflow-gaging stations equipped for continuous recording of data were installed in October 1989 at Garfoot and Brewery Creeks at the same locations as gaging stations from the previous study (fig. 1). Measurements of streamflow were made according to standard USGS methods (Rantz and others, 1982). Streamflow measurements were made every 4 to 6 weeks, and more frequently during high flows, to define a stage-streamflow relation for each site.

Each gaging station was equipped with a stage-activated refrigerated water sampler for automatic collection of water samples representing high flows. A data logger was programmed to collect a sample with each $0.2-\mathrm{ft}$ increase in stage once the stream stage reached an initial sampling threshold. After the stream stage peaked, a sample was collected with each $0.4-\mathrm{ft}$ decrease in stage. The sampling strategy was designed to collect most samples during increasing stage when the constituent concentrations of interest would be changing the most. The samples, which were chilled to $4^{\circ} \mathrm{C}$ after collection, were analyzed for suspended sediment, total phosphorus, and ammonia nitrogen. Samples collected were selected for analysis to represent variation in water quality over a range of increasing and decreasing stages.

In addition to the automated samples, manual samples were collected at a fixed interval approximately every 2 weeks in the spring, summer, and fall and once a month
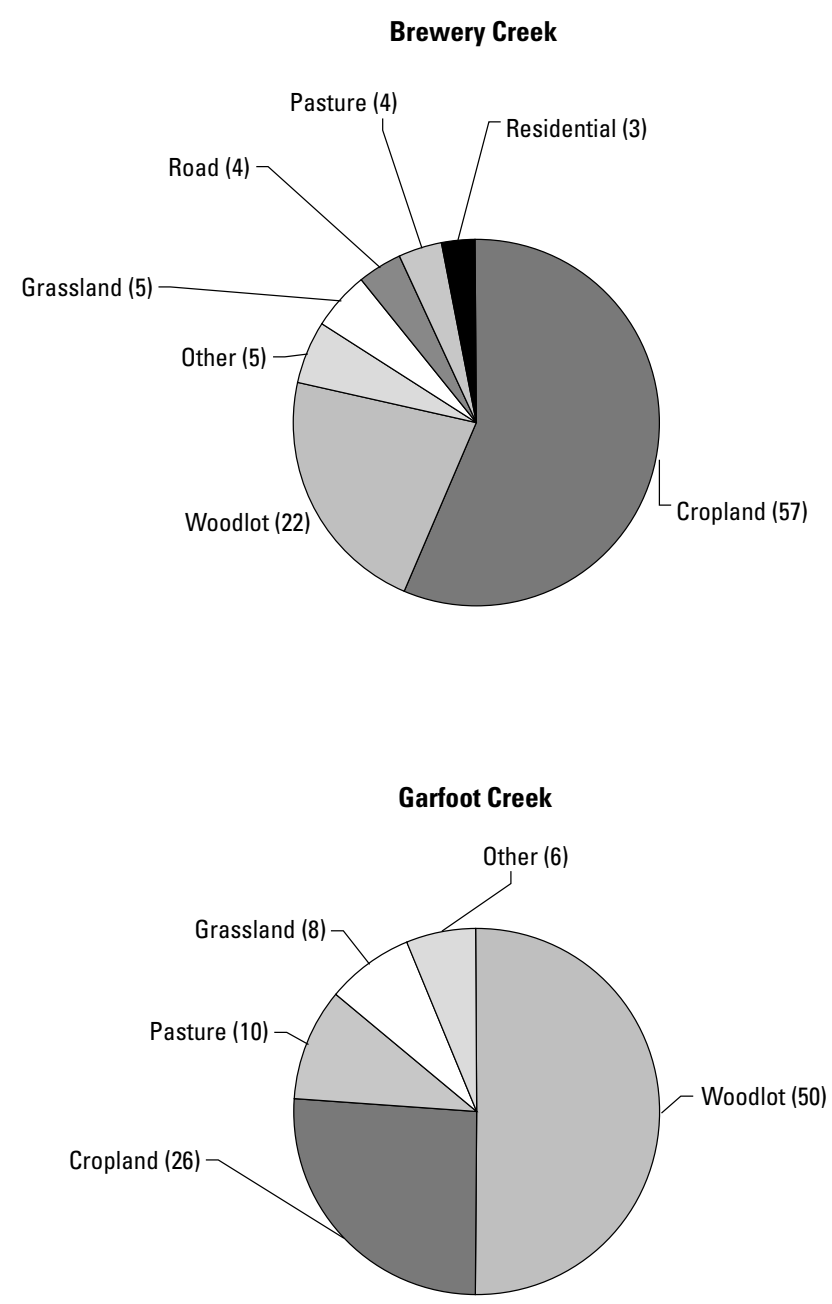

Figure 2. Percentage of total land use and land cover for Brewery and Garfoot Creek watersheds, Dane County, Wis.

in the winter. Samples were integrated over the depth and width of the stream by use of a hand-held sampler (Edwards and Glysson, 1988). The fixed-interval samples were analyzed for suspended sediment, total phosphorus, and ammonia nitrogen.

The suspended-sediment samples were analyzed by the USGS sediment laboratory in Iowa City, Iowa according to USGS methods (Guy, 1973). Total phosphorus and ammonia nitrogen were determined by the Wisconsin Laboratory of Hygiene according to standard methods (American Public Health Association, 1985; Wisconsin Laboratory of Hygiene, 1992).

Precipitation during the previous study was measured at one location at the approximate centroid of each watershed. Precipitation was collected in an 8-in. collector, which drained into a 3-in.-inside-diameter standpipe. Precipitation measurements were made every 15 minutes. 
Precipitation was collected during nonfreezing periods only (March 1-November 30) at the two sites.

In October 1989, three rain gages were installed in each watershed (fig. 1). One rain gage was at the site of the rain gage from the previous study. The other two rain gages were sited by trial-and-error to result in approximately equal Thiessen polygon areas. Thiessen polygons represent the areas in closest proximity to each rain gage; the average precipitation was computed as a weighted average using the Thiessen polygon areas as the weighting factor (Viessman and others, 1977). Thus, because the Thiessen polygon areas are approximately equal, the

Table 1. Summary of eligible and implemented rural best-management practices in the Brewery and Garfoot Creek watersheds, Wis.

[ft, feet; BMP's, best-management practices. Table contains revisions to a BMP table previously published in Rappold and others (1997), which are the result of changes in practices eligible or implemented. Data are number of sites unless otherwise noted]

\begin{tabular}{|c|c|c|}
\hline \multicolumn{3}{|c|}{ Evaluation monitoring watershed } \\
\hline Practice & Brewery Creek & Garfoot Creek \\
\hline \multicolumn{3}{|c|}{ Animal-waste management } \\
\hline Eligible barnyard-runoff control systems & $20^{\mathrm{a}}$ & $7^{\mathrm{a}}$ \\
\hline Implemented barnyard-runoff control systems & $10^{\mathrm{b}}$ & 5 \\
\hline \multicolumn{3}{|c|}{ Streambank protection } \\
\hline Eligible streambank protection $^{c}$ & $22,000 \mathrm{ft}$ & $16,800 \mathrm{ft}$ \\
\hline Implemented streambank protection $^{\mathrm{c}}$ & $19,100 \mathrm{ft}$ & $16,700 \mathrm{ft}$ \\
\hline Eligible Fencing & $1,200 \mathrm{ft}$ & $5,475 \mathrm{ft}$ \\
\hline Implemented fencing & $0^{c}$ & $5,475 \mathrm{ft}$ \\
\hline Contracted stream crossing & 1 & 4 \\
\hline Implemented stream crossing & 1 & 4 \\
\hline Contracted grade stabilization & 2 & 2 \\
\hline Implemented grade stabilization & $2^{\mathrm{d}}$ & 2 \\
\hline \multicolumn{3}{|c|}{ Upland management } \\
\hline Eligible nutrient management & 2,440 acres & 590 acres \\
\hline Implemented nutrient management & 1,415 acres & 155 acres \\
\hline Eligible upland BMPs ${ }^{\mathrm{e}}$ & 5,170 acres & 1,520 acres \\
\hline Implemented upland BMPs ${ }^{\mathrm{e}}$ & 1,145 acres & 285 acres \\
\hline \multicolumn{2}{|c|}{${ }^{\mathrm{b}}$ Total includes a barnyard-control system installed by landowner without cost-share funding. } & \\
\hline \multicolumn{3}{|c|}{$\begin{array}{l}{ }^{c} \text { The contracts for length of streambank protection reflect the total length of each practice. } \\
\text { One eroded site can include various practices, such as riprap, shoreline and streambank stabiliza- } \\
\text { tion, and shoreline buffers. Both banks may have been eroded and/or implemented with BMPs. }\end{array}$} \\
\hline \multicolumn{3}{|l|}{${ }^{\mathrm{d}}$ Site eligible for BMP no longer has livestock. } \\
\hline $\begin{array}{l}{ }^{\mathrm{e}} \text { Includes an individual practice or series of practice } \\
\text { result in a reduced pollutant source, such as contour fa } \\
\text { cropping, grassed waterways, and reduced tillage. }\end{array}$ & $\begin{array}{l}\text { ther than nutrient } \\
\text { ing, contour strip c }\end{array}$ & $\begin{array}{l}\text { nanagement, that } \\
\text { opping, field strip }\end{array}$ \\
\hline
\end{tabular}

arithmetic average of the precipitation at the three rain gages is approximately equal to the average precipitation for a given watershed. Precipitation was collected in an 8 -in. collector that drained into a tipping bucket rain gage. Each tip represented 0.01 in. of rain; all rainfall data were recorded every 5 minutes.

\section{Selection and Inventory of Watersheds}

Inventory of the rural watersheds began in 1992 to provide information on land-use and land-treatment changes that may affect water quality. A geographic information system (GIS) database contains the land-use and BMP inventories. Watershed boundaries, hydrography, roads, streams, woodlot, rain gages and BMPs were digitized from 1:24000 topographic maps. Farm-field and parcel mapping was done by the Dane County Regional Planning Commission. Detailed descriptions of each watershed and the BMP program are reported in Rappold and others (1997), and Wierl and others (1996).

The Priority Watersheds Program selected, assessed, and approved the Black Earth Creek project between 1985 and 1989. Voluntary signup period for BMPs started in March 1989 and ended in March 1997. Monitoring of the post-BMP implementation started when the majority of practices were installed and operational. The post-BMP implementation period began in the Brewery Creek watershed on October 1, 1996, and at Garfoot Creek watershed in April 1, 1997.

Eligible, and installed BMPs for Garfoot and Brewery Creek watersheds are summarized in table 1. Annual updates of practices-barnyard-runoff control, streambank protection, and upland control—were obtained by contacting the Dane County Land Conservation Office. Barnyard-runoff control systems are installed to reduce the amount of organic matter reaching the stream by improving the cattle lots and adding filter strips. Streambank protection 


\section{EXPLANATION}

Implemented streambank protection BMP

Stream

Eligible barnyard runoff BMP

$\diamond$ Installed barnyard runoff BMP

Barnyard no longer has livestock
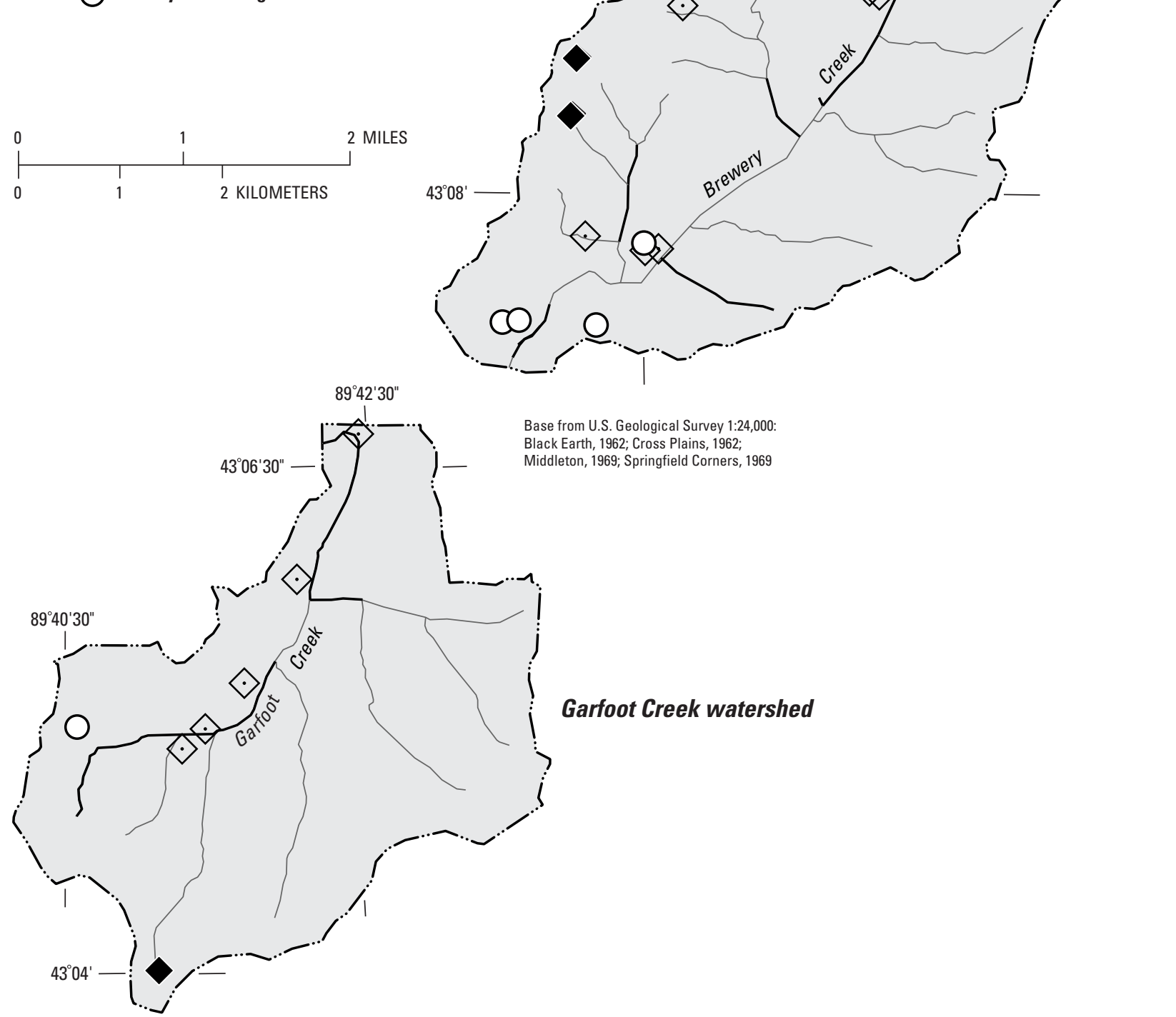

Figure 3. Eligible and implemented best-management practices (BMPs), Brewery and Garfoot Creek watersheds, Dane County, Wis. 
reduces the amount of sediment reaching the stream by limiting cattle access and stabilizing streambanks by various practices, including fencing and installation of watering areas in the stream. Upland-control practices reduce the amount of sediment and phosphorus by cropland and manure management on highly erodible lands.

In 1999, a majority of the goals set by the WDNR and local Land Conservation Department had been achieved in the Garfoot and Brewery Creeks Watersheds. Additional practices could be implemented for several years, but it was felt that most sources of nonpoint pollution had been controlled by the implemented practices. The land-use tracking was discontinued in 1999 when the post-monitoring phase ended. The status of barnyard and streambank-protection practices as of 1999 is shown in figure 3 .

\section{Hydrologic Conditions During the Study Period}

\section{Precipitation}

The 30-year normal precipitation for the study area was 30.88 in. at the National Oceanic Atmospheric Administration (NOAA) weather station at the Madison, Wis., airport (National Oceanic and Atmospheric Administration, 2000). Data from the rain gages in the middle of each watershed show that the annual rainfall was substantially above the 30-year normal (1961-90) for 3 of the 11 years monitored at Brewery Creek (1985, 1986, and 1993) and 4 of the 11 years monitored at Garfoot Creek (1985, 1986, 1993, and 1998); in both watersheds, rainfall was substantially below the 30 -year normal during 1 year: 1997 for Brewery Creek and 1990 for Garfoot Creek (fig. 4). The largest deviation between annual precipitation and the 30-year normal was in water year 1993 for both of the rain gages (fig. 4). At Brewery Creek, the annual

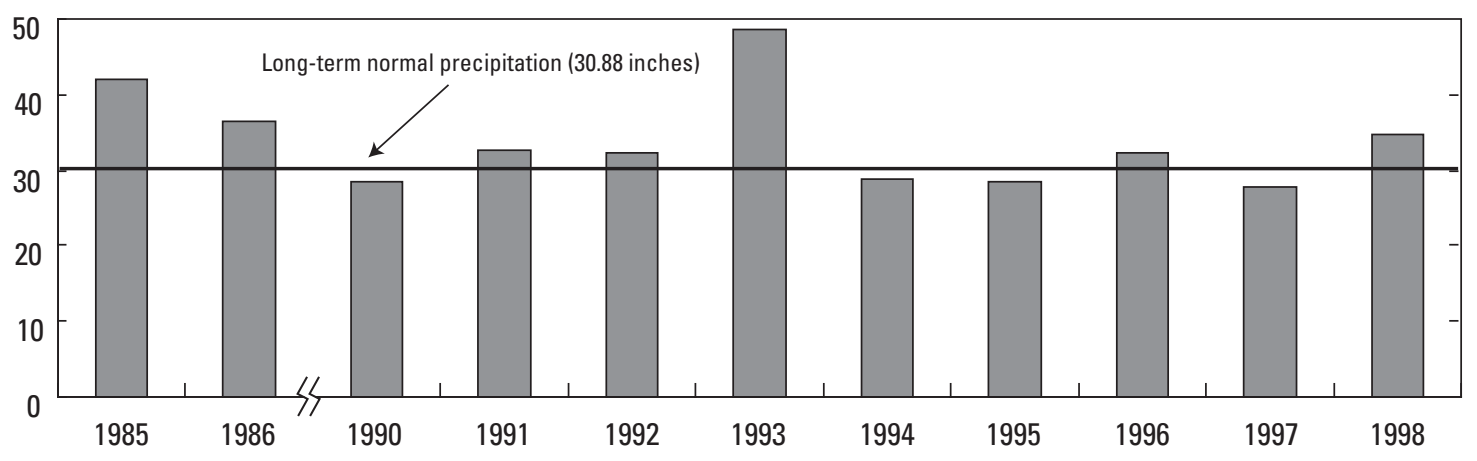

WATER YEAR
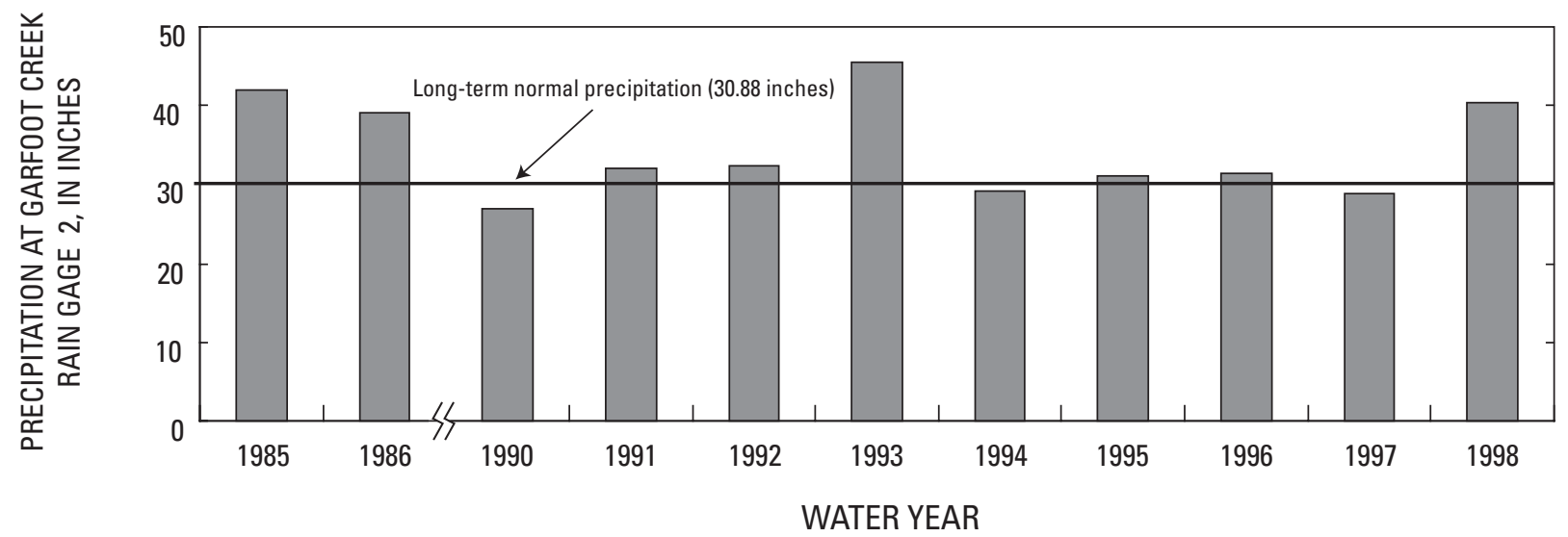

Figure 4. Yearly precipitation at Brewery and Garfoot Creeks and 1961-90 normal precipitation at Madison, Wis. 
precipitation was $48.6 \mathrm{in}$. in 1993, which was $17.7 \mathrm{in}$. above the long-term annual normal (fig. 4). At Garfoot Creek, the annual precipitation was 45.4 in. in water year 1993 which was $14.5 \mathrm{in}$. above the annual long-term normal (fig. 4). Ninety-three and 96 percent of the above normal precipitation fell in 4 months at Brewery and Garfoot, respectively, in water year 1993. The largest deviation between monthly precipitation and the long-term normal for July was in 1993 (3.4 in.). At Brewery Creek, the July 1993 total monthly rainfall was 11.2 in., which was 7.8 in. above normal. The total monthly precipitation for July 1993 was 9.9 in. at Garfoot Creek, which was 6.5 in. above normal.

At Brewery Creek, the lowest annual precipitation was 27.7 in. in water year 1997, which is $3.2 \mathrm{in}$. below the long-term normal. The lowest annual precipitation measured at Garfoot Creek was 26.9 in. in water year 1990, which is $4.0 \mathrm{in}$. below the annual long-term normal.

A Kendall test for trend (Helsel and Hirsch, 1992) was done for the precipitation data collected at the Brewery Creek and Garfoot rain gages for the 11 years of record. No statistically significant trend (at the 5-percent significance level) was found in the annual precipitation at either site. A Kendall test for trend also was done for annual precipitation for 11 years of record at the NOAA rain gage at the Madison airport. Again, no statistically significant trend was found at the 5-percent significance level. Annual precipitation at the NOAA rain gage for the 1954-98 period also had no statistically significant trend. The 1954-98 periods corresponds to the streamflow data
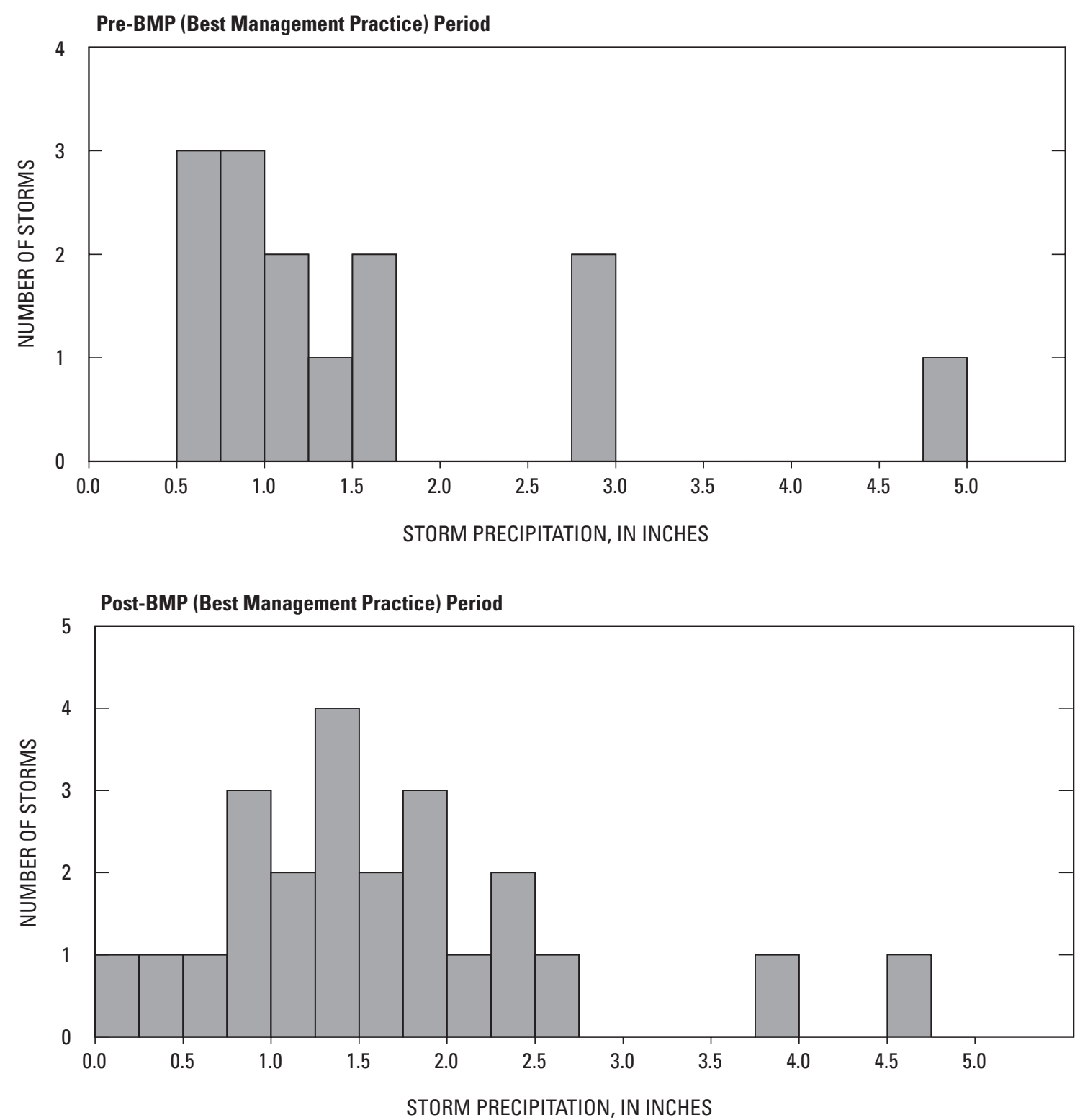

Figure 5. Histograms of precipitation events at Brewery Creek, Dane County, Wis., for which storm loads were calculated. 
collected at a USGS long-term gaging station at Black Earth Creek near Black Earth (fig.1).

Histograms are presented for rainstorms for which storm loads were calculated for Brewery and Garfoot Creeks (figs. 5 and 6). At Brewery Creek during the preBMP period (1985 and 1986 water years), 11 precipitation events amounting to less than 2 in. produced surface runoff and subsequent storm loads (fig. 5). Two precipitation rainstorms were in the 2- to 4-in. range, and one precipitation rainstorm was greater than 4 in. (fig. 5). During the post-BMP period, there were 17 rainstorms with less than 2 in. of total rain (fig. 5). Five rainstorms were between 2- to 4 in. range, and one rainstorm had a total rainfall greater than 4 in. (fig. 5). At Brewery Creek, three fewer rainstorms produced surface runoff and storm loads in the pre-BMP period than in the post-BMP period. More rainstorms in the post-BMP period had rainfall between 2 and 4 in.

At Garfoot Creek during the pre-BMP period (1985-86 and 1990 water years), there were 14 rainstorms with less than $2 \mathrm{in.} \mathrm{of} \mathrm{total} \mathrm{rainfall.} \mathrm{Three} \mathrm{rainstorms} \mathrm{had}$ a total rainfall between 2 and 4 in. and one rainstorm had a total precipitation greater than 4 in. (fig. 6). During the post-BMP period, 15 rainstorms had total rainfall of less than 2 in., 1 rainstorm had between 2 and 4 in., and 1 rainstorm had total precipitation greater than 4 in. (fig. 6). The distributions of pre- and post-BMP rainstorms that produced storm runoff are similar. There was one

\section{Pre-BMP (Best Management Practice) Period}
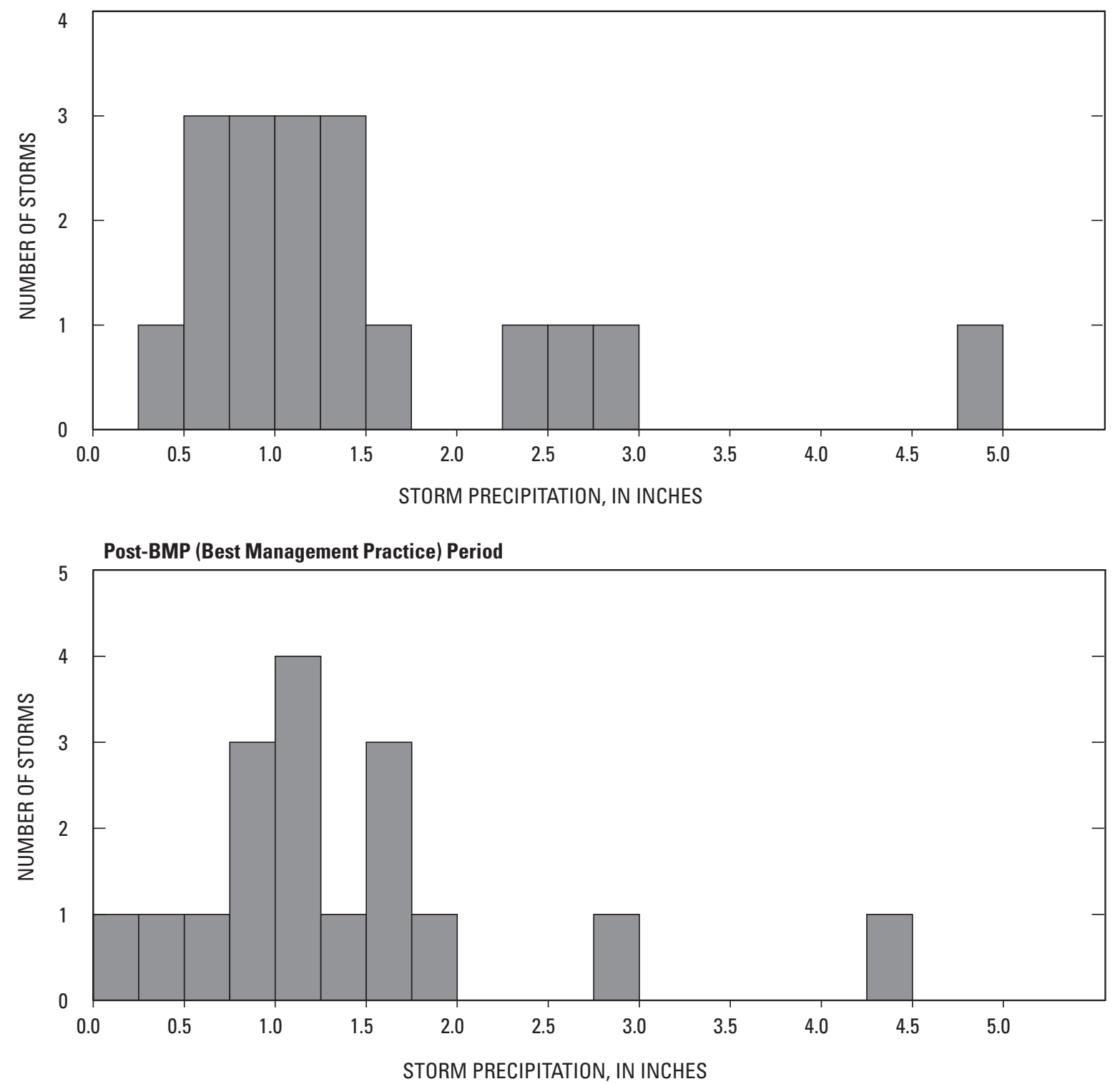

Figure 6. Histograms of precipitation events at Garfoot Creek, Dane County, Wis., for which storm loads were calculated. 
more rainstorm in the post-BMP period with less than 2 in. of rain compared to the pre-BMP periods. The main difference is that there were more rainstorms between 2 and 4 in. in the pre-BMP period. For the most part, the distributions for rainstorms that produced surface runoff and storm loads were similar in the pre- and post-BMP periods for both Brewery and Garfoot Creeks.

\section{Streamflow}

At Brewery Creek, the mean annual streamflow for the study period was $2.4 \mathrm{ft}^{3} / \mathrm{s}$ (table 2); the minimum annual streamflow was $0.58 \mathrm{ft}^{3} / \mathrm{s}$ in water year 1991, and the maximum annual streamflow was $4.3 \mathrm{ft}^{3} / \mathrm{s}$ in water year 1993 (fig. 7). At Garfoot Creek, the mean annual streamflow for the study period was $5.2 \mathrm{ft}^{3} / \mathrm{s}$ (table 2); the maximum annual streamflow was $7.7 \mathrm{ft}^{3} / \mathrm{s}$ in water year 1993, and the minimum annual streamflow was $3.2 \mathrm{ft}^{3} / \mathrm{s}$ in water year 1990 (fig. 8). The mean annual streamflow at Black Earth Creek near Black Earth for water years 195498 was $35 \mathrm{ft}^{3} / \mathrm{s}$ (table 2); the minimum annual streamflow was $27 \mathrm{ft}^{3} / \mathrm{s}$ in water year 1990 (fig. 9), and the maximum annual streamflow was $61 \mathrm{ft}^{3} / \mathrm{s}$ in water year 1993

(fig. 9). At Brewery Creek, the mean annual streamflow for the pre-BMP period was $3.1 \mathrm{ft}^{3} / \mathrm{s}$, whereas the mean annual streamflow for the post-BMP period was $2.2 \mathrm{ft}^{3} / \mathrm{s}$. At Garfoot Creek, the mean annual streamflow for the pre- and post-BMP periods were $4.9 \mathrm{ft}^{3} / \mathrm{s}$ and $5.8 \mathrm{ft}^{3} / \mathrm{s}$, respectively (table 2 ).

Streamflow data collected as part of this study were used to determine the streamflow characteristics at the Garfoot, Brewery, and Black Earth Creek gaging stations
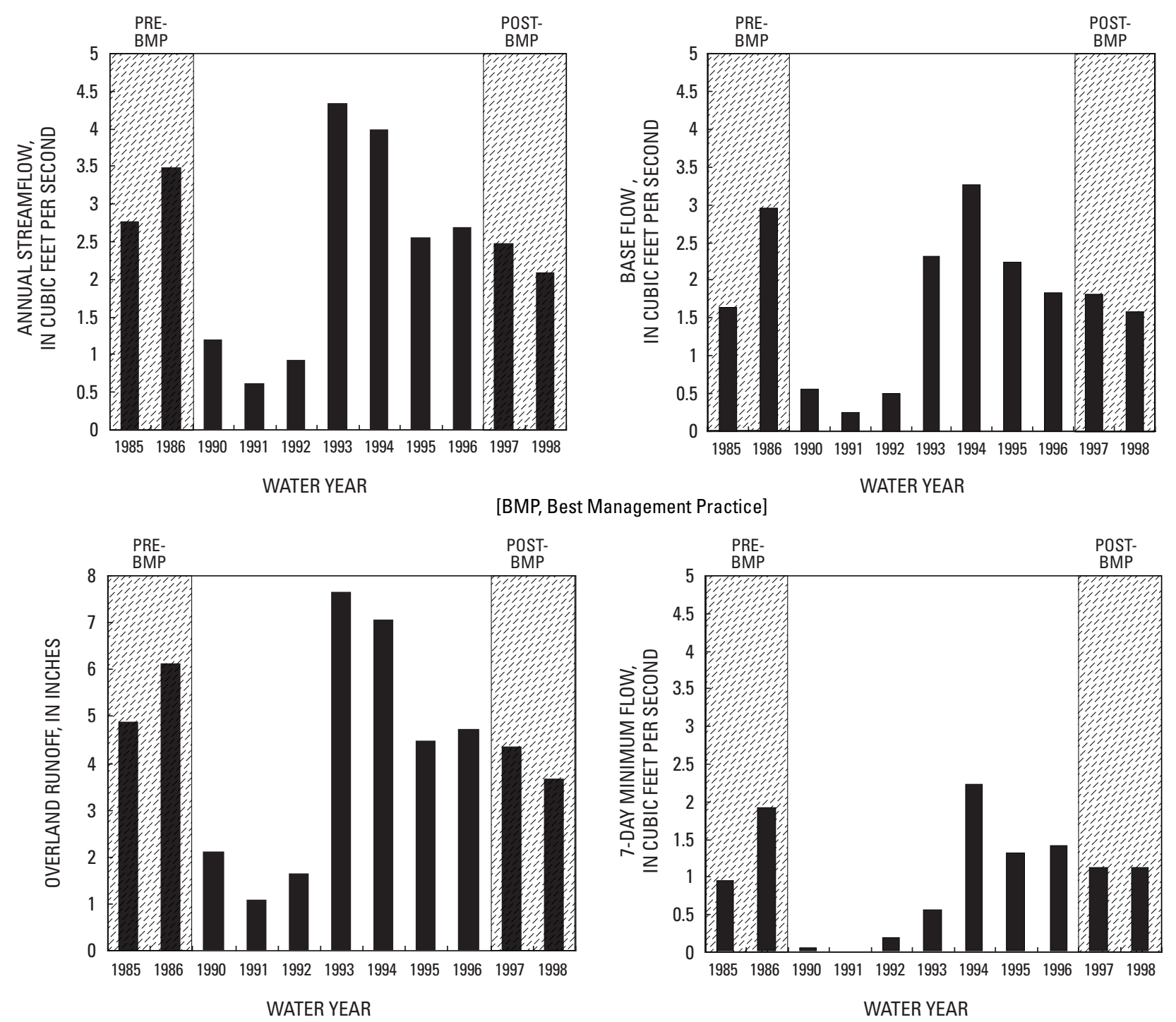

Figure 7. Streamflow characteristics for Brewery Creek, Dane County, Wis. 
Table 2. Summary of streamflow characteristics for Brewery, Garfoot, and Black Earth Creeks, Wis., pre- and post-BMP periods [BMP, best-management practice; WY, water year]

\begin{tabular}{|c|c|c|c|c|c|c|c|c|c|}
\hline & \multicolumn{3}{|c|}{ Brewery Creek } & \multicolumn{3}{|c|}{ Garfoot Creek } & \multicolumn{3}{|c|}{ Black Earth Creek } \\
\hline $\begin{array}{l}\text { (cubic feet } \\
\text { per second, } \\
\text { unless noted) }\end{array}$ & $\begin{array}{l}\text { Pre-BMP } \\
\text { 10/84-9/86 }\end{array}$ & $\begin{array}{l}\text { Post-BMP } \\
10 / 96-9 / 98\end{array}$ & $\begin{array}{l}\text { Period } \\
\text { of } \\
\text { record }\end{array}$ & $\begin{array}{l}\text { Pre-BMP }^{a} \\
10 / 84-4 / 90\end{array}$ & $\begin{array}{c}\text { Post-BMP } \\
4 / 96-9 / 98\end{array}$ & $\begin{array}{l}\text { Period } \\
\text { of } \\
\text { record }\end{array}$ & $\begin{array}{l}\text { Pre-BMP } \\
\text { WY 85-86 }\end{array}$ & $\begin{array}{l}\text { Post-BMP } \\
\text { WY 97-98 }\end{array}$ & $\begin{array}{l}\text { Period } \\
\text { of record } \\
\text { WY 54-98 }\end{array}$ \\
\hline $\begin{array}{l}\text { Mean annual } \\
\text { streamflow }\end{array}$ & 3.08 & 2.25 & 2.43 & 4.93 & 5.76 & 5.23 & 50.8 & 41.7 & 34.9 \\
\hline $\begin{array}{l}\text { Minimum 7-day } \\
\text { low flow }\end{array}$ & .93 & 1.1 & 0 & 1.8 & 2.60 & 1.8 & 29.0 & 23.0 & 13 \\
\hline Mean base flow & 2.30 & 1.70 & 1.72 & 4.19 & 4.90 & 4.42 & 43.6 & 35.4 & 29.6 \\
\hline Mean base flow ${ }^{\mathrm{b}}$ & 73 & 76 & 67 & 84 & 85 & 85 & 86 & 84 & 85 \\
\hline
\end{tabular}

(fig. 1). In addition, the streamflow data were needed to determine the nutrient and sediment loads at the Brewery and Garfoot Creek gaging stations. Base flow represents ground-water discharge to the stream channel. Base flow was separated from the daily mean streamflows over the period of study (1984-98) by methods described in White and Sloto (1990). Overland runoff-the difference between the annual mean discharge and base flow-is water that flows over the land surface and enters the stream. Daily streamflow data for the gaging stations for all the water years of the study period are published in "Water Resources Data, Wisconsin, Water Years 1985-1998" (Holmstrom and others, 1986, 1987, 1990-99).

The highest annual streamflow at all three stations was in water year 1993. The annual streamflow at Black Earth Creek in 1993 was 175 percent of the mean for the period of record (44 years) and was the highest annual streamflow ever recorded at the station. This streamflow corresponds to the greatest annual precipitation measured at the study-site rain gages and the greatest annual precipitation measured at the NOAA weather station at Madison for the period of data collection. The minimum annual streamflow occurred in water year 1991 at Brewery Creek and in water year 1990 at Garfoot Creek and Black Earth Creek (figs. 7, 8, and 9). At Brewery Creek in water year 1991, the 7-day mean low flow was zero (fig. 7).

A frequency analysis of annual peak at streamflows at Black Earth Creek near Black Earth for 1954-98 was done using the log-Pearson Type III procedure following Bulletin 17-B guidelines for annual peaks (Interagency Advisory Committee on Water Data, 1982). The estimated peak streamflows for selected frequencies are presented in table 3 . The peak streamflows $\left(1,320 \mathrm{ft}^{3} / \mathrm{s}\right)$ for the period of record at Black Earth Creek occurred in 1993. This flood peak was between the 25- and 50-year recurrence interval (table 3).

A Kendall test for trend was done for all of the streamflow characteristics for the study period at Brewery, Garfoot, and Black Earth Creeks. None of the streamflow characteristics had a statistically significant trend for the study period. The Kendall test for trend also was done for Black Earth Creek for annual streamflow, base flow, and overland runoff for 1954-98. A statistically significant upward trend was found for annual streamflow and base flow but not for overland runoff for Black Earth Creek near Black Earth (table 4). Because annual streamflow is the sum of annualized base flow and overland runoff, the increase in annual streamflow may be caused by the increase in base flow.

Table 3. Peak streamflow and selected recurrence intervals for Black Earth Creek, Wis., 1954-98

[ft $3 / \mathrm{s}$, cubic feet per second]

\begin{tabular}{cc}
\hline $\begin{array}{c}\text { Recurrence interval } \\
\text { (years) }\end{array}$ & $\begin{array}{c}\text { Peak streamflow } \\
\text { (ft } \mathbf{3} / \mathbf{s})\end{array}$ \\
\hline 1.25 & 251 \\
2 & 432 \\
5 & 725 \\
10 & 939 \\
25 & 1,226 \\
50 & 1,450 \\
\hline
\end{tabular}


Table 4. Results of the Kendall test of trend in streamflow characteristics, Black Earth Creek near Black Earth, Wis., water years 1954-98

[ft $\mathrm{f}^{3} / \mathrm{s}$, cubic foot per second; <, less than]

\begin{tabular}{lccc}
\hline \multicolumn{1}{c}{$\begin{array}{c}\text { Streamflow } \\
\text { characteristic }\end{array}$} & $\begin{array}{c}\text { Kendall } \\
\text { Tau }\end{array}$ & $\begin{array}{c}\text { Trend slope } \\
\text { estimate } \\
\left(\mathbf{f t t}^{3} / \mathbf{s}\right)\end{array}$ & $\begin{array}{c}\text { Significance } \\
\text { level }\end{array}$ \\
\hline Annual streamflow & 0.36 & 0.3766 & $<0.01$ \\
Base flow & .11 & .3502 & $<.01$ \\
Overland runoff & .11 & .0267 & .28 \\
\hline
\end{tabular}

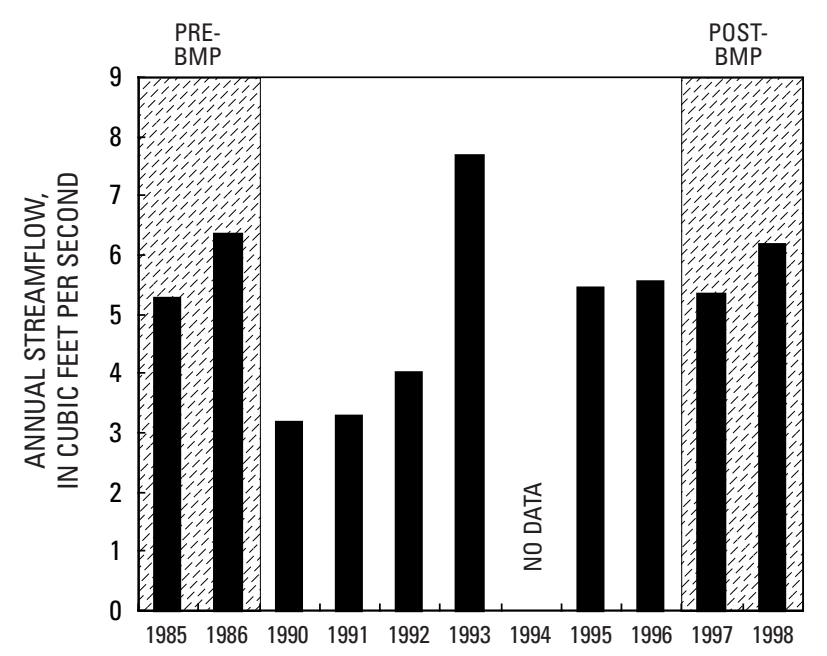

WATER YEAR

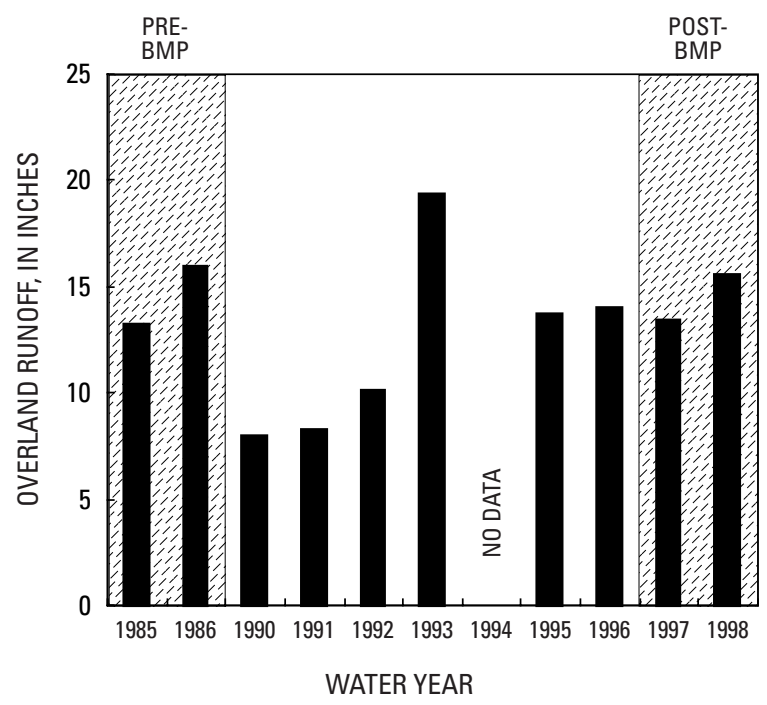

Since 1960, there have been three periods of apparently increasing annual streamflow and base flow for the Black Earth Creek area near Black Earth, Wis. (fig. 10). The first increase was in the mid-1970s, the second during the mid-1980s, and the last from about 1992 to 1995 (fig. 10). As noted previously, no statistically significant trend was found in annual precipitation at the Madison airport rain gage. The increase in the annual streamflow, which likely is related to base flow (ground-waterseepage to the stream) of Black Earth Creek corresponds to increasing snowfall. Krohelski and others (2002) found a good correlation between increasing snowfall and periods of increasing base flow of Black Earth Creek in south-central Wisconsin. Snowfall is one of the sources

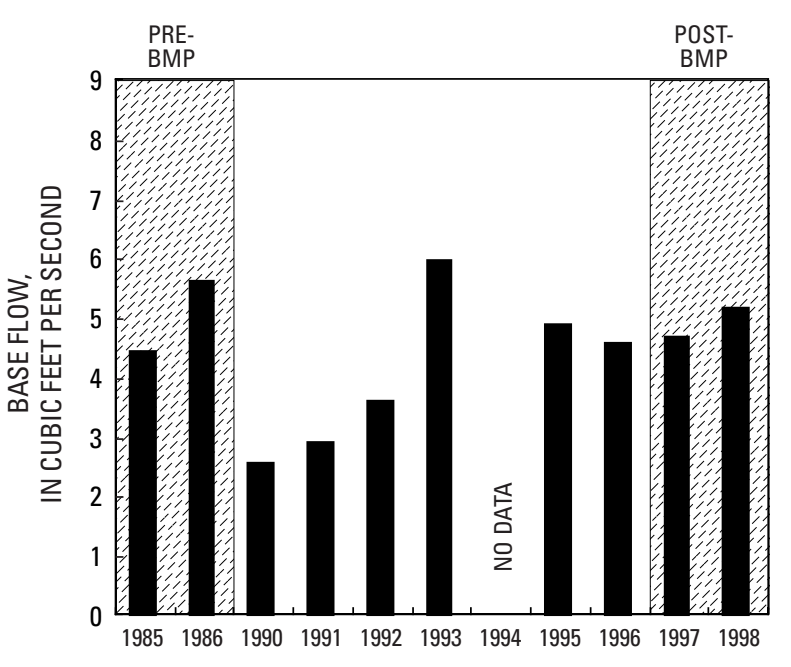

WATER YEAR

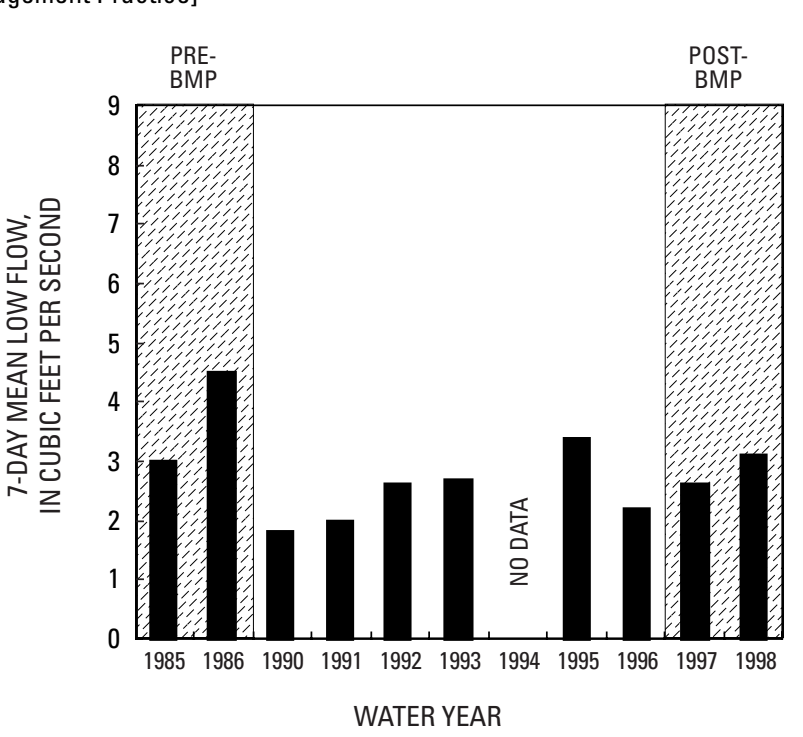

Figure 8. Streamflow characteristics for Garfoot Creek, Dane County, Wis. 
of recharge to the ground-water system in south-central Wisconsin. In addition, changing land practices in the watershed may have increased the infiltration rate and hence increased base flow. Gebert and Krug (1996) found similar trends in other sites in southwestern Wisconsin. Even though an increase is apparent in annual streamflow and base flow in the latter part of the study period (fig. 10), no statistically significant trend was found. This result may be due more to the short time period (11 years) than to absence of a trend. Although the annual streamflows and base flows indicate a cyclical pattern (fig. 10), the overall flows appear to be increasing.

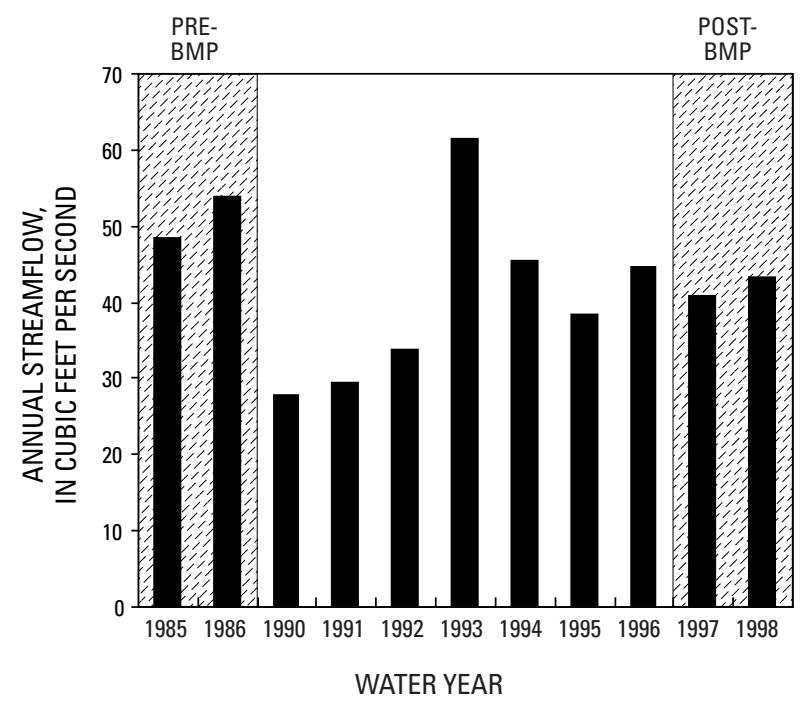

[BMP, Best Management Practice]
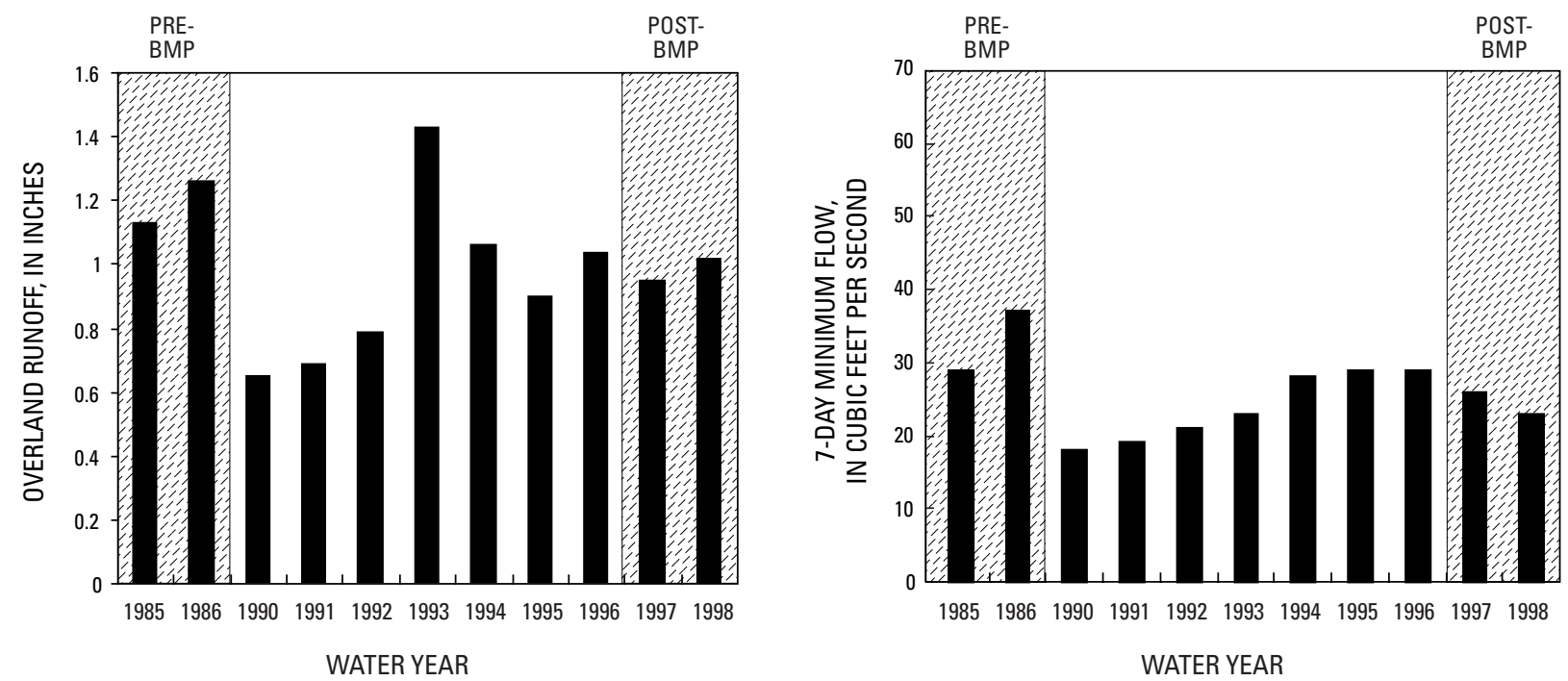

\section{Water Quality Before and After Installation of Best-Management Practices}

\section{Nutrient and Sediment Concentrations at Base Flow}

Because base flow of a stream consists of groundwater discharge to the stream, base-flow water quality generally reflects ground-water quality. Consequently, base-flow water quality may be affected by land-use practices in the watershed that affect ground water.

Concentrations of nutrients, for example, may become

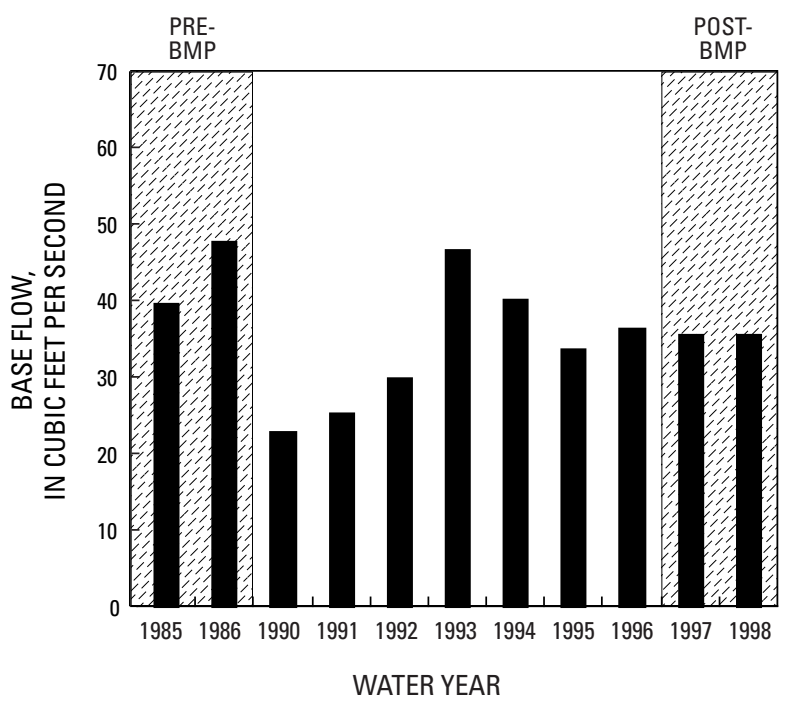

WATER YEAR

WATER YEAR

Figure 9. Streamflow characteristics for Black Earth Creek, Dane County, Wis. 

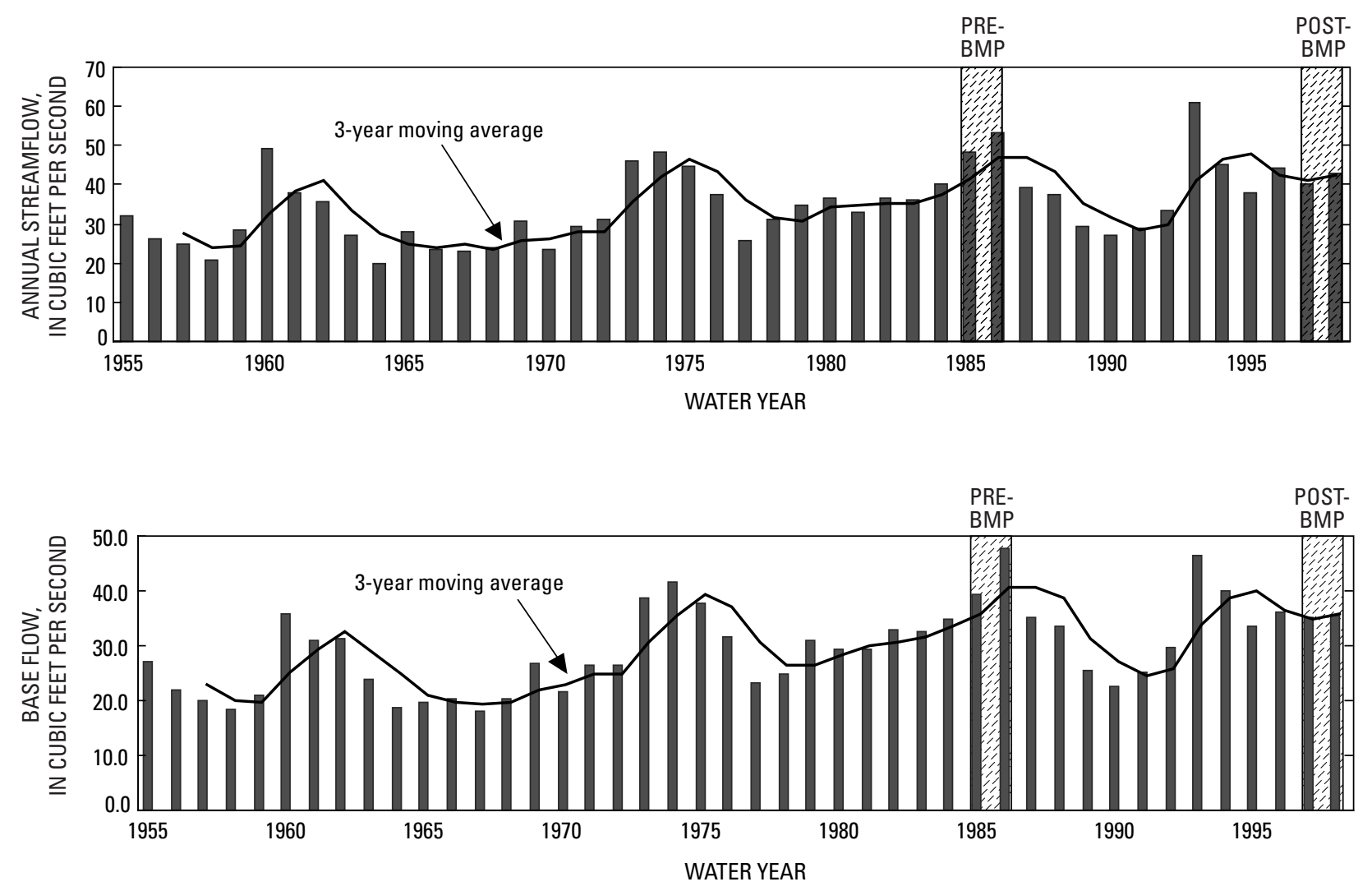

[BMP, Best Management Practice]

Figure 10. Annual streamflow and base flow with 3-year moving average for Black Earth Creek, Dane County, Wis., 1955-98 water years.

elevated above background concentrations in ground water as a result of agricultural activities.

Comparisons of base-flow water quality concentrations during the pre- and post-BMP periods may indicate changes due to BMPs. A nonparametric Wilcoxon ranksum test can be used to determine whether significant differences are present between two independent periods (pre- and post-BMP). The null hypothesis is that median of selected constituents at base flow during the pre-BMP period are the same as those in the post-BMP period. The alternative hypothesis is that the median concentrations at base flow in the post-BMP period are less than those during the pre-BMP period. If the alternative hypothesis appears to be true, then the reduction may be a result of changing land-use practices in the watershed.

Water-quality samples were collected at base flow during the pre- and post-BMP periods. Daily mean streamflows were separated into overland flow and base flow to determine whether a sample collected was during a base-flow period, the ratio of instantaneous streamflow and daily mean base flow was calculated. If the ratio of instantaneous discharge to daily mean base flow was less than or equal to 0.95 , then a sample collected on this day was considered to be a potential base-flow sample. In addition, an overland-flow time lag was calculated. The time lag was equal to the drainage area raised to the 0.2 power and rounded up to the next day (Viessman and others, 1977). The overland- flow time lag was determined to be 2 days for both Garfoot and Brewery Creeks. If a potential base-flow sample was collected within 2 days of the peak of a hydrograph rise, this sample was not considered to be a base-flow sample. The remaining potential baseflow samples then were evaluated on the basis of their hydrograph position relative to preceding storms.

The Wilcoxon rank-sum nonparametric test of the median (MathSoft, 2000) was applied to the pre-BMP and post-BMP concentrations for the base-flow samples. Results of the Wilcoxon rank-sum test can be found in table 5. Concentration of the base-flow samples for Brewery and Garfoot Creeks are shown in figures 11 and 12. Also shown on these figures is the median for each constituent by water year. 

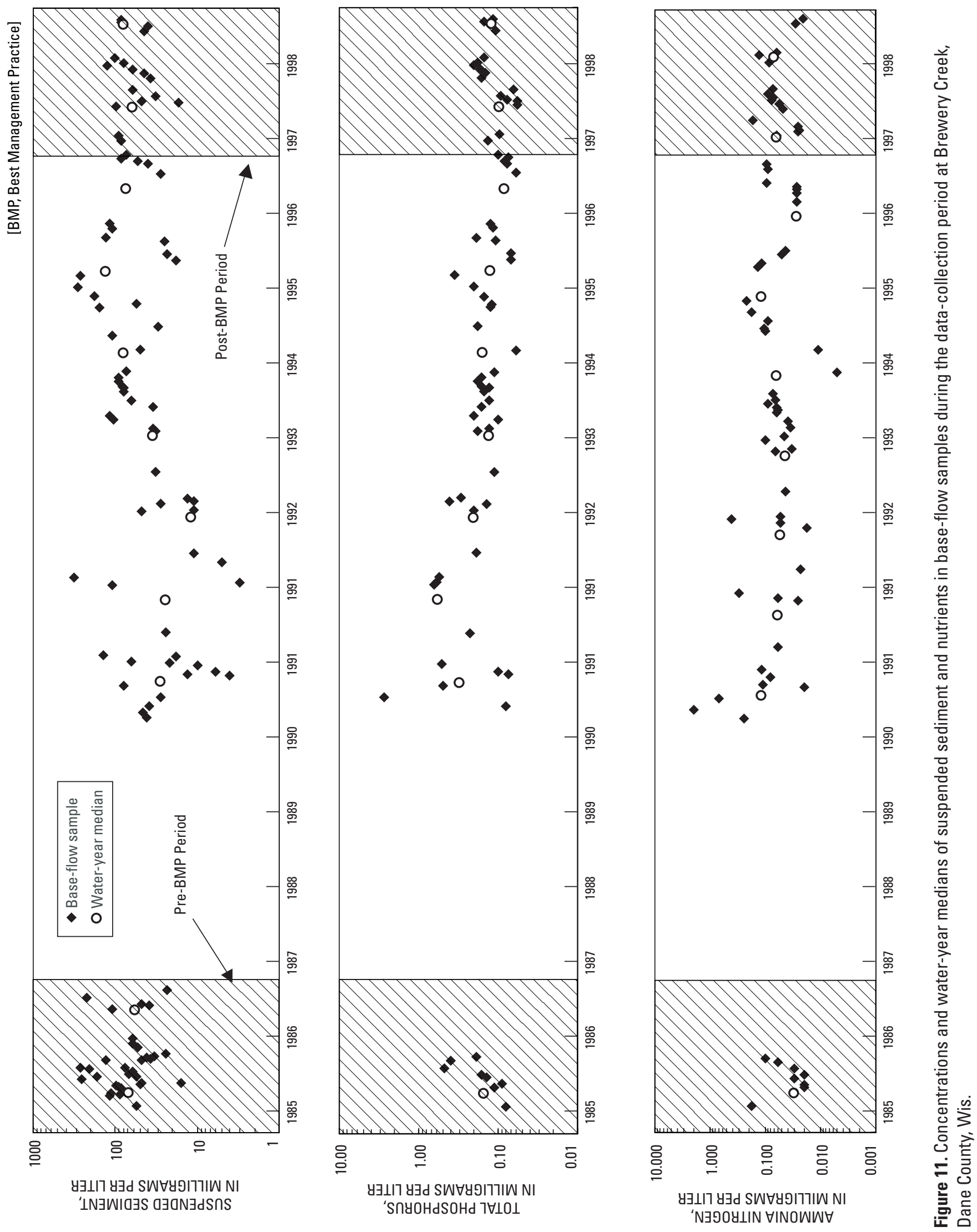


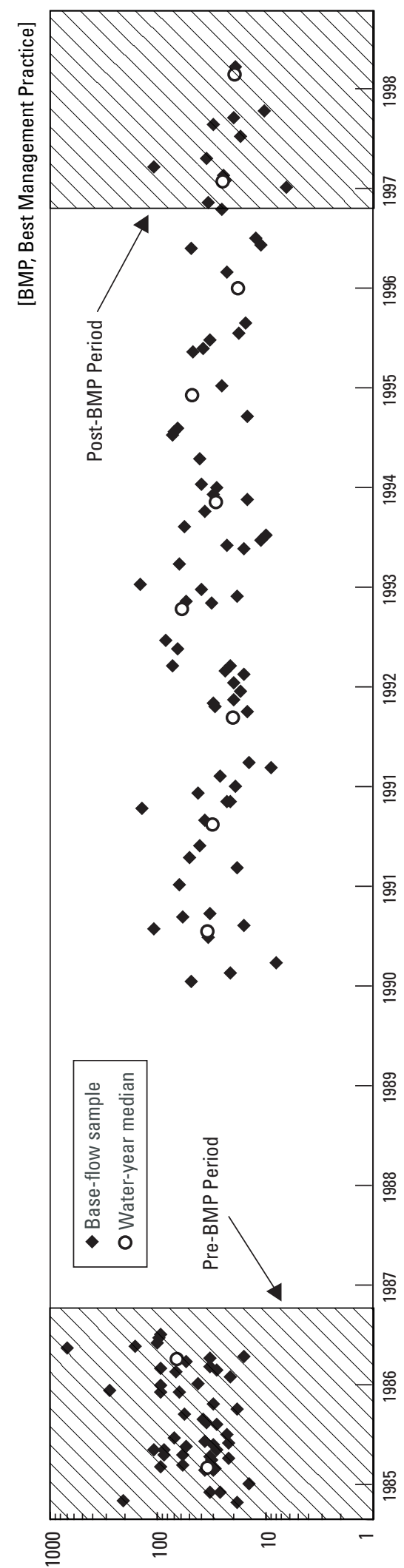

y 'IN

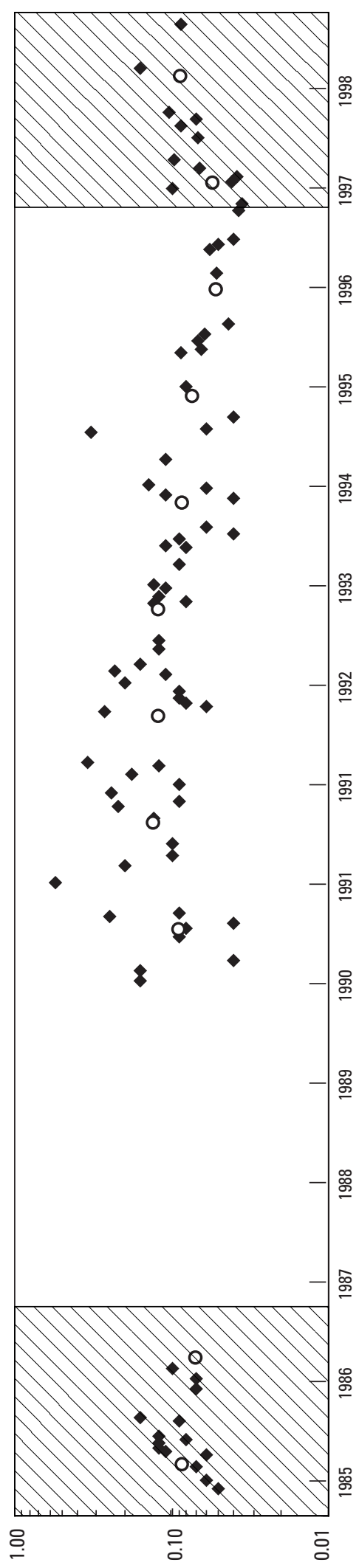

y 'SกYOHdSOHd 7 $\forall I O \perp$

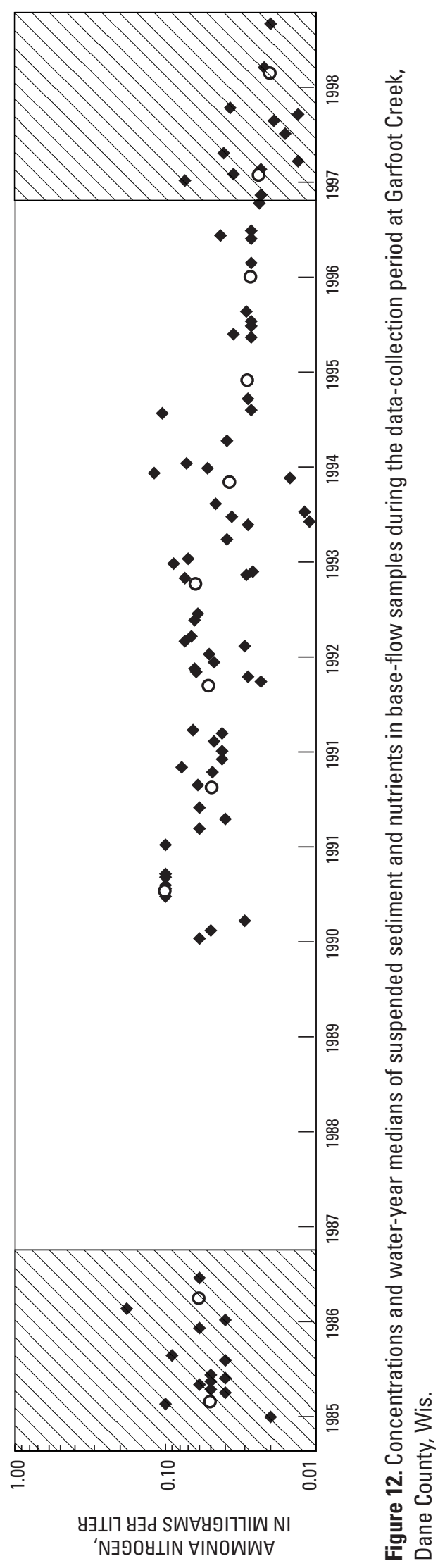


Table 5. Results of the Wilcoxon rank-sum test on the median concentrations of suspended sediments and nutrients at base flow, pre- and post-BMP periods, Brewery and Garfoot Creeks, Wis.

[mg/L, milligrams per liter; BMP, best-management practice]

\begin{tabular}{|c|c|c|c|}
\hline \multicolumn{4}{|c|}{ Median concentration, mg/L } \\
\hline Dependent variable & Pre-BMP & Post-BMP & Significance level \\
\hline \multicolumn{4}{|c|}{ Brewery Creek } \\
\hline Suspended sediment & 62.0 & 54.6 & 0.127 \\
\hline Total phosphorus & .15 & .12 & .105 \\
\hline Ammonia nitrogen & .03 & .064 & .872 \\
\hline \multicolumn{4}{|c|}{ Garfoot Creek } \\
\hline Suspended sediment & 37.5 & 22.0 & .016 \\
\hline Total phosphorus & .09 & .08 & .166 \\
\hline Ammonia nitrogen & .06 & .020 & .001 \\
\hline
\end{tabular}

For Brewery Creek, none of the differences in the median water-quality concentrations for the pre- and postBMP periods were statistically significant at the 0.05 level (table 5; values less than 0.05 are significant). For Garfoot Creek, the 41-percent decrease in the median suspended sediment concentration between the pre- and post-BMP periods is statistically significant at the 0.05 level (table 5). The 67-percent decrease in ammonia nitrogen median concentration between the pre- and post-BMP periods also was statistically significant at the 0.05 level (table 5). The slight decrease in total phosphorus median concentration between the pre-and post-BMP periods was not statistically significant at the 0.05 level (table 5).

\section{Storm Loads}

Because a great deal of the annual sediment and nutrient transport occurs during storms, fixed-interval sampling, particularly at a monthly frequency, may not show changes resulting from BMP implementation (Walker, 1993). Consequently, mass transport resulting from individual storms was analyzed. Instantaneous mass transport of a particular constituent is determined by multiplying streamflow by the concentration of the constituent and a conversion factor (Porterfield, 1972). The integration method was then used to determine the mass transport of each constituent for each storm (Porterfield, 1972), expressed as a storm load. Concentration at the beginning of a storm was estimated from samples collected during previous base-flow periods between storms. Concentration at the end of the storm was estimated from samples collected immediately after the end of the storm. Some concentration data for individual storms were estimated by the relation between concentration and streamflow. Estimated data samples within a storm period were kept to a minimum.

In many cases, the variability in the storm loads is large enough to mask potential differences in the pre- and post-BMP periods. In addition, because the pre- and post-BMP periods arise from different hydrologic conditions, differences in the hydrologic conditions could result in differences that are not a result of the management practices. For these reasons, one solution is to perform regressions relating the storm loads to variables representing climatic and seasonal conditions. If the independent variables represent the natural climatologic and seasonal conditions, then the variability remaining in the regression residuals represents the combination of lack-of-fit for the regression model and changes induced by the BMPs. Because the regression, by design, reduces the variability in the data, in theory it should be possible to detect smaller differences between the pre- and post-BMP periods compared to detecting differences in the storm loads.

A number of independent variables were selected, most of which were based on various measures of precipitation for each distinct rainstorm. These variables included total rainfall $(\mathrm{P})$, the 15- and 30-minute maximum intensities $\left(\mathrm{I}_{15}\right.$ and $\left.\mathrm{I}_{30}\right)$, and the Universal Soil Less Equation (USLE) erosivity index (EI; Wischmeier and Smith, 1978). Additional precipitation-based measures included the 1-, 3- and 5-day antecedent precipitation ( $\mathrm{API}_{1}, \mathrm{API}_{3}$ and API $_{5}$ ), which is computed as the total rainfall for the 1,3 , and 5 days prior to the beginning of each storm, respectively. Terms combining total rainfall and the antecedent precipitation also were considered (for example, $\mathrm{P}+\mathrm{API}_{1}$ ). Finally, two seasonal terms were included to allow for variations arising solely based on the time of year. The seasonal terms were based on the serial date of the storm (T), using a period of 1 year and both sine and cosine terms to allow for amplitude and phase-shift estimation.

Preliminary regression results indicated that for many of the constituents and storms, simple linear regressions resulted in the prediction of negative storm loads. Because these negative loads would result in erroneous conclusions when comparing pre- and post-BMP periods, the final regressions were based on a logarithmic transformation of the storm loads, thus assuring that negative loads cannot be 
predicted. For each creek and constituent, stepwise regressions were done using the independent variables described above (table 6). For each regression, additional variables were considered if the improvement in the resulting regression was considered large enough to warrant the use of additional variables. In addition, various regression plots were examined to verify that the underlying assumptions of regression analysis were not violated.

For both Brewery and Garfoot Creeks, the median storm loads for all three constituents for the pre-BMP and post-BMP periods are listed in table 7 . The two periods were compared statistically by means of the Wilcoxon rank-sum test as described previously. Along with the test applied to the storm loads, the regression residuals also were tested for differences between the pre- and post-BMP periods (table 7). If the regressions represent the variability due to natural factors, a difference in the regression residuals could be attributed directly to a difference due to the BMPs.

For Brewery Creek, ammonia nitrogen was the only median storm load that decreased, and the decrease was not statistically significant at the 0.05 level (table 7). There are three potential reasons that the differences are not statistically significant. First, the difference may be due entirely to chance, so the difference is not a result of the BMPs. Second, differences in the underlying natural conditions (precipitation amount and intensity, seasonal distribution of storms, and so forth) between the pre- and post-BMP periods may be obscuring a real difference. Third, the variability in the data may be large enough to obscure a real difference. For the first two reasons, there is no way to determine whether a nonsignificant difference is due to chance or differences in the underlying conditions. Because the regression residuals will have a smaller variability (the regression removes some of the variability through the relation with the independent variables), testing the regression residuals could reduce the variability enough to reveal a true difference between the two periods. For Brewery Creek, this result appears to be the case for ammonia nitrogen, where the difference in storm load residuals between the pre- and post-BMP periods is statistically significant at the 0.05 level (table 7). Therefore, for ammonia nitrogen, the difference in pre- and post-BMP conditions is likely due to the BMPs installed.

For Garfoot Creek, only the median storm load for ammonia nitrogen shows a statistically significant difference between the pre- and post-BMP periods (table 7). The decrease in ammonia nitrogen was 66 percent. The test applied to the regression residuals shows that the differences in load residuals for both total phosphorus and ammonia nitrogen are statistically significant at the 0.05 level (table 7). Therefore, the reduction in pre- and post-BMP conditions for total phosphorus and ammonia nitrogen is likely due to the BMPs installed.

Table 6. Regression results for storm loads at Brewery and Garfoot Creeks, Wis.

[P, total rainfall; EI, Universal Soil Loss Equation Erosivity Index; API ${ }_{n}$, antecedent rainfall $\mathrm{n}$ days before the storm; $\mathrm{I}_{\mathrm{n}}$, $\mathrm{n}$-minute maximum precipitation intensity; T, starting date of streamflow period, in years since 1904; $\cos \left(\right.$ ), trigonometric cosine function; $\sin \left(\right.$ ), trigonometric sine function; $\mathrm{R}^{2}$, fraction of variation explained by the regression]

\begin{tabular}{|c|c|c|c|c|c|}
\hline Dependent variable & $\begin{array}{l}\text { Independent } \\
\text { variables }\end{array}$ & Sample size & Adjusted $\mathbf{R}^{2}$ & Standard error & $\begin{array}{c}\text { Standard error, } \\
\text { percent }\end{array}$ \\
\hline \multicolumn{6}{|c|}{ Brewery Creek } \\
\hline Suspended sediment & $\begin{array}{l}\mathrm{P}+\mathrm{API}_{1}, \mathrm{I}_{15}, \cos (\mathrm{T}) \\
\quad \sin (\mathrm{T})\end{array}$ & 29 & 0.829 & 0.733 & 34 \\
\hline Total phosphorus & $\begin{array}{l}\mathrm{P}+\mathrm{API}_{1}, \mathrm{I}_{15}, \cos (\mathrm{T}) \\
\quad \sin (\mathrm{T})\end{array}$ & 26 & .790 & .672 & 16 \\
\hline Ammonia nitrogen & $\mathrm{EI}, \cos (\mathrm{T}), \sin (\mathrm{T})$ & 24 & .635 & .946 & 31 \\
\hline \multicolumn{6}{|c|}{ Garfoot Creek } \\
\hline Suspended sediment & $\begin{array}{l}\mathrm{P}+\mathrm{API}_{3}, \mathrm{I}_{30}, \cos (\mathrm{T}) \\
\quad \sin (\mathrm{T})\end{array}$ & 31 & .651 & .737 & 28 \\
\hline Total phosphorus & $\begin{array}{l}\mathrm{P}+\mathrm{API}_{1}, \cos (\mathrm{T}) \\
\quad \sin (\mathrm{T})\end{array}$ & 33 & .594 & .748 & 17 \\
\hline Ammonia nitrogen & $\begin{array}{l}\mathrm{P}+\mathrm{API}_{3}, \cos (\mathrm{T}) \\
\quad \sin (\mathrm{T})\end{array}$ & 31 & .642 & .613 & 20 \\
\hline
\end{tabular}




\section{Effects of Specific Management Practices}

Concentrations of nutrients and sediment observed during base-flow conditions and storms can be reduced by BMPs. For the purpose of discussion, BMPs can be divided into five main categories: animal-wastemanagement systems, fencing, streambank protection, nutrient management, and upland-control practices (University of Wisconsin Extension, 1998). Because each watershed is affected by a mixture of BMPs and each BMP has varying success in controlling different aspects of water quality, it is useful to consider a matrix of interactions between the BMPs and the potential water-quality change caused by BMPs. In this matrix (table 8), the direction of each arrow indicates whether the water quality is likely to improve (downward indicating a decrease in concentration) or degrade (upward indicating an increase in concentration). The size of each arrow indicates how likely the BMPs would be to change the water quality of the stream. A small arrow indicates some effect on the water quality but may not cause a significant change. A large arrow indicates likelihood of significant change in water quality. A horizontal bar indicates that the BMP may have little effect or an unknown effect on the stream-water quality. A separate matrix for a generalized watershed, for the Brewery Creek watershed and for the Garfoot Creek watershed, is included in table 8 . The last row under each of the matrices indicates the observed effect for Brewery Creek and Garfoot Creek watersheds of the implementation of BMPs in the watershed.

Animal-waste-management systems are used to control phosphorus and ammonia nitrogen loading to a stream. BMPs for controlling barnyard wastes include directing clean surface water around the barnyard, constructing settling basins or filter walls, and establishing vegetated filter strips (University of Wisconsin Extension, 1998). Controlling animal wastes should have a noticeable effect on storm loads of phosphorus and ammonia nitrogen by eliminating the direct runoff of manure and urine (table 8 ). The effect on the base-flow water quality may be less. Streams that flow through a barnyard or that are directly connected to a barnyard by a ditch or pipe can achieve reductions in the base-flow concentration of phosphorus and ammonia nitrogen by eliminating this waste stream. On the other hand, animal-waste systems that emphasize infiltration into the ground-water-flow system may increase the base-flow concentrations of phosphorus. Animal-waste-management systems should have little or no effect on the suspended-sediment concentration or suspended sediment load (table 8).

By restricting access of cattle, streambank fencing allows vegetative stabilization of the streambank. This stabilization should reduce bank erosion during high flows and should lead to lower suspended-sediment and totalphosphorus loads. Base-flow suspended-sediment concentrations also should be reduced if cattle access

Table 7. Results of the Wilcoxon rank-sum test comparing storm loads and storm-load residuals for pre- and post-BMP periods at Brewery and Garfoot Creeks, Wis.

[BMP, best management practice]

\begin{tabular}{lcccccc}
\hline & \multicolumn{3}{c}{ Median storm loads, pounds $^{1}$} & \multicolumn{2}{c}{ Storm load residuals } \\
\hline Dependent variable & Pre-BMP & Post-BMP & $\begin{array}{c}\text { Direction } \\
\text { of change }\end{array}$ & $\begin{array}{c}\text { Significance } \\
\text { level }\end{array}$ & $\begin{array}{c}\text { Direction } \\
\text { of change }\end{array}$ & $\begin{array}{c}\text { Significance } \\
\text { level }\end{array}$ \\
\hline \multicolumn{7}{c}{ Brewery Creek } \\
Suspended sediment & 3.4 & 4.9 & Increase & 0.244 & Increase & 0.930 \\
Total phosphorus & 46.6 & 55.1 & Increase & .696 & Increase & .959 \\
Ammonia nitrogen & 29.8 & 9.0 & Decrease & .292 & Decrease & .026 \\
\hline & 16.6 & 6.6 & Decrease & .149 & Decrease & .280 \\
\hline Suspended sediment & 114 & 38.8 & Decrease & .066 & Decrease & .044 \\
Total phosphorus & 36.6 & 12.5 & Decrease & .006 & Decrease & .005 \\
Ammonia nitrogen & \multicolumn{7}{c}{ Garfoot Creek } \\
\hline
\end{tabular}

${ }^{1}$ Suspended-sediment loads are in tons 
Table 8. Matrix of interactions between BMPs and different aspects of water quality, with statistical tests results from comparing pre- to post-BMP periods for a generalized watershed, and Brewery and Garfoot Creek Watersheds, Wis.

[BMP, best-management practices; N/C, no change; \%, percent; --, no expected affect on water quality]

$\checkmark$ Statistically significant improvement in water quality expected

$\Downarrow$ Improvement in water quality expected

$\downarrow \uparrow \quad$ Water quality could either improve or degrade

$\uparrow$ Degradation of water quality expected

\begin{tabular}{|c|c|c|c|c|c|c|c|}
\hline \multirow{2}{*}{\multicolumn{2}{|c|}{ Best management practices }} & \multicolumn{2}{|c|}{ Sediment } & \multicolumn{2}{|c|}{ Phosphorus } & \multicolumn{2}{|c|}{ Ammonia nitrogen } \\
\hline & & Base flow & Storm & Base flow & Storm & Base flow & Storm \\
\hline \multicolumn{8}{|c|}{ Generalized Watershed } \\
\hline \multicolumn{2}{|c|}{ Animal-waste-management systems } & -- & -- & $\downarrow \uparrow$ & $\downarrow$ & $\downarrow \uparrow$ & $\downarrow$ \\
\hline \multicolumn{2}{|l|}{ Fencing } & $\downarrow$ & $\downarrow$ & $\downarrow$ & $\downarrow$ & $\downarrow$ & -- \\
\hline \multicolumn{2}{|l|}{ Streambank protection } & $\downarrow$ & $\downarrow$ & $\downarrow$ & $\downarrow$ & -- & -- \\
\hline \multicolumn{2}{|l|}{ Nutrient management } & -- & -- & $\sqrt{ }$ & $\checkmark$ & $\downarrow$ & $\downarrow$ \\
\hline \multicolumn{2}{|l|}{ Upland-control practices } & -- & $\downarrow$ & $\downarrow$ & $\checkmark$ & -- & -- \\
\hline \multicolumn{8}{|c|}{ Brewery Creek Watershed } \\
\hline \multirow[b]{2}{*}{$\begin{array}{l}\text { Best management } \\
\text { practices }\end{array}$} & & \multicolumn{2}{|c|}{ Sediment } & \multicolumn{2}{|c|}{ Phosphorus } & \multicolumn{2}{|c|}{ Ammonia nitrogen } \\
\hline & $\begin{array}{c}\text { Status } \\
(\%)\end{array}$ & Base flow & Storm & Base flow & Storm & Base flow & Storm \\
\hline $\begin{array}{l}\text { Animal-waste-management } \\
\text { systems }\end{array}$ & 75 & -- & -- & $\Downarrow \uparrow$ & $\downarrow$ & $\downarrow \uparrow$ & $\sqrt{2}$ \\
\hline Fencing & 0 & -- & -- & -- & -- & -- & -- \\
\hline Streambank protection & 90 & -- & $\checkmark$ & -- & $\downarrow$ & -- & -- \\
\hline Nutrient management & 50 & -- & -- & & $\downarrow$ & -- & -- \\
\hline Upland-control practices & 20 & -- & $\downarrow$ & $\uparrow$ & $\downarrow$ & -- & -- \\
\hline \multicolumn{2}{|l|}{ Observed effect } & $\mathrm{N} / \mathrm{C}$ & $\mathrm{N} / \mathrm{C}$ & $\mathrm{N} / \mathrm{C}$ & $\mathrm{N} / \mathrm{C}$ & $\mathrm{N} / \mathrm{C}$ & $\checkmark$ \\
\hline \multicolumn{8}{|c|}{ Garfoot Creek Watershed } \\
\hline \multirow[b]{2}{*}{$\begin{array}{l}\text { Best management } \\
\text { practices }\end{array}$} & & \multicolumn{2}{|c|}{ Sediment } & \multicolumn{2}{|c|}{ Phosphorus } & \multicolumn{2}{|c|}{ Ammonia nitrogen } \\
\hline & $\begin{array}{c}\text { Status } \\
(\%)\end{array}$ & Base flow & Storm & Base flow & Storm & Base flow & Storm \\
\hline $\begin{array}{l}\text { Animal-waste-management } \\
\text { systems }\end{array}$ & 70 & $\sqrt{2}$ & -- & $\Downarrow \uparrow$ & $\checkmark$ & $\downarrow$ & $\checkmark$ \\
\hline Fencing & 100 & -- & $\downarrow$ & $\downarrow$ & $\downarrow$ & $\downarrow$ & -- \\
\hline Streambank protection & 100 & $\sqrt{2}$ & $\checkmark$ & $\downarrow$ & $\downarrow$ & $\checkmark$ & -- \\
\hline Nutrient management & 30 & -- & -- & $\downarrow$ & $\downarrow$ & -- & -- \\
\hline Upland-control practices & 20 & -- & $\boldsymbol{\top}$ & $\uparrow$ & $\downarrow$ & -- & -- \\
\hline Observed effect & & $\sqrt{2}$ & $\mathrm{~N} / \mathrm{C}$ & $\mathrm{N} / \mathrm{C}$ & $\sqrt{2}$ & $\downarrow$ & 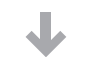 \\
\hline
\end{tabular}


to the channel and streambank is restricted. Base-flow concentrations of ammonia nitrogen and total phosphorus from animal waste could be reduced by not allowing cattle direct access to the stream.

Streambank-protection practices include stabilizing shoreline, shaping and seeding streambanks, and rehabilitating fishery habitat (University of Wisconsin Extension, 1998). Streambank-protection systems typically will reduce erosion by restricting cattle access and stabilizing eroded streambanks. By protecting the streambanks, sedimentation and nutrient delivery to the stream (that is, phosphorus attached to soil particles) will be reduced. Base-flow sediment concentration and sediment storms loads should be reduced after implementation of streambank protection (table 8). Phosphorus base-flow concentration and storm loads may be reduced by implementation of streambank protection, but the effect will be less than the effect on suspended-sediment concentration and storm load (table 8). Ammonia nitrogen concentration in base-flow streamflow and storm loads should be affected minimally by streambank protection (table 8 ).

Nutrient-management practices (University of Wisonsin-Extension, 1998), which include use of recommended fertilizer and manure application rates, should reduce phosphorus and ammonia nitrogen concentration and loads during both base-flow and storm conditions (table 8). Nutrient management should have no effect on suspended sediment.

Upland-protection practices, which are designed to prevent and control sheet and rill erosion, include changes in crop rotation, change of permanent cover, minimum or reduced tillage, contour and strip cropping, and grassed waterways. The main effect on streamwater quality from upland protection will be to reduce suspended-sediment concentration and loads during storms (table 8). Phosphorus storm loads also will be reduced if the soil-attached phosphorus is a major contributor to the stream phosphorus load. Because upland-protection practices encourage infiltration, they potentially could increase concentrations of phosphorus in the ground-water system, which could increase base-flow concentrations.

In Brewery Creek, 80-95 percent of the suspended sediment reaching Brewery Creek was estimated to be from eroding cropland (Wisconsin Department of Natural Resources, 1989). Because the level of upland protection was low ( 20 percent) of the potential land area, the expected effects from these practices would be diminished (table 8). For this watershed, only ammonia nitrogen during storms showed a statistically significant decrease between the pre- and post-BMP periods (table 8). The source of ammonia nitrogen to the stream is likely from animal waste. The sources of total phosphorus load to the stream are barnyards and soil with attached phosphorus. Even though 70 percent of the barnyards were controlled by runoff-control systems and removal of livestock, the potential improvement in total-phosphorus loads are likely being masked by a continuing supply of phosphorus attached to sediment from upland erosion of croplands. Benefits of the BMPs also may be masked by location of controlled barnyards. These barnyards are off the main stem of Brewery Creek, so the effects of the controls may not be apparent at the gaging station and watershed outlet.

An estimated 90 percent of sediment reaching Garfoot Creek was from eroding croplands (Wisconsin Department of Natural Resources, 1989). Only 20 percent of upland protection was implemented in the watershed. With this low level of upland protection implemented, a decrease in suspended-sediment loads during storms is expected (table 8). Yet, for this watershed, both suspendedsediment and ammonia nitrogen concentrations in base flow decreased significantly between the pre- and postBMP periods. A major source of ammonia nitrogen to the stream is from animal waste (Wisconsin Department of Natural Resources, 1989). Barnyard-runoff controls were implemented at five of seven eligible barnyards. Garfoot Creek flowed through two of these barnyards, and a third drained directly to the creek (fig. 3). After the barnyard controls were implemented, this source of ammonia nitrogen during base-flow periods was eliminated, and the postBMP ammonia nitrogen was less than the pre-BMP period.

Suspended-sediment concentration also was reduced, as indicated by comparing pre- and post-BMP implementation low-flow periods. One of the management practices implemented was fencing. Approximately 1 mile of fencing was installed along Garfoot Creek (table 1 and table 8), most of it along the main stem. The watershed plan (Wisconsin Department of Natural Resources, 1989) indicated that streambank erosion along Garfoot Creek was minimal but cattle had access to two sites with eroding and trampled banks and one site controlled by fencing. Fencing also is a component of barnyard controls. A barnyard directly upstream from the gage was controlled, and animals were excluded from the stream except at a watering area. Fencing the stream prevents animals from wading in the stream and resuspending sediment that would be transported downstream during base flow.

Total-phosphorus and ammonia-nitrogen loads during storms in the Garfoot Creek watershed showed a statistically significant decrease between the pre- and post-BMP periods. An important source of total phosphorus and 
ammonia nitrogen in the Garfoot Creek watershed is animal waste (Wisconsin Department of Natural Resources, 1989). In the Garfoot Creek watershed, five of seven barnyards had runoff-control systems implemented. These five barnyards all were along the main stem of Garfoot Creek (fig. 3), and two of these had the highest estimated barnyard phosphorus loads in the watershed (Wisconsin Department of Natural Resources, 1989). Controlling these barnyards resulted in a significant reduction of nutrient loads in the streams.

In contrast, the barnyard BMPs that were installed in the Brewery Creek watershed were effective in reducing the storm loads of ammonia nitrogen but were not effective in reducing the total phosphorus loads. The source of total phosphorus in the Brewery Creek watershed is from animal waste and phosphorus that is attached to sediment. The suspended sediment in the Brewery Creek watershed is fine (silt and clay) and has a greater capacity to bind total phosphorus than the coarse-grained sediments (sand) that predominate in the Garfoot Creek watershed. The installed barnyard-control systems have reduced the total phosphorus loads from animal waste but would not have controlled the total phosphorus load that is transported to the creek from upland erosion. Therefore, the Brewery Creek watershed likely will continue to be a source of phosphorus, either as direct overland transport or from resuspended sediment in the channel.

Suspended-sediment loads during storms did not show a significant decrease between the pre-and post-BMP periods at either the Brewery Creek or Garfoot Creek watershed. At Garfoot Creek, there was a statistically significant decrease in the suspended-sediment concentration during base-flow periods. At high flows, the suspended sediment that has been deposited in the channel previously (years of deposition) probably is being resuspended. To detect a significant difference between the pre-and post-BMP periods, suspended-sediment monitoring likely would have to continue for years in the future.

The effects of the BMPs on water quality are watershed specific. The effectiveness of the BMPs will depend on the type, number, and location of the controls implemented. In addition, the sources of the contaminants to the watershed will determine whether the practices are effective. If the soil substrate is sandy and barnyards are numerous, then the source of total phosphorus will be from animal wastes, and barnyard controls may be highly effective (Garfoot Creek). If the soils are transported easily and the source of phosphorus is from phosphorus attached to soil particles, then barnyard controls may not be as effective (Brewery Creek).

\section{Summary and Conclusions}

The U.S. Geological Survey, in cooperation with the Wisconsin Department of Natural Resources, began a comprehensive, multi-disciplinary evaluation-monitoring program in 1989 to assess the effectiveness of the Wisconsin Nonpoint Source Program. Hydrologic and water-quality data were collected at Brewery and Garfoot Creeks in 1984 and 985 (pre-BMP period) and 1997 and 1998 (postBMP period). BMPs installed in these two basins included conservation tillage, contour strip-cropping, streambank protection, and various barnyard-runoff controls.

Water-quality samples were collected during baseflow and storm conditions for two periods: pre- and postBMP implementation. Samples were analyzed for suspended sediment, total phosphorus, and ammonia nitrogen. At Brewery Creek, no statistically significant differences were found in the median concentrations of the waterquality constituents at base flow between pre- and postBMP periods. At Garfoot Creek, the median suspendedsediment concentrations between the pre- and post-BMP periods decreased by 41 percent, and the difference is statistically significant at the 0.05 level. The median ammonia nitrogen concentrations of base-flow samples between the pre- and post-BMP periods decreased by 67 percent, and the difference was statistically significant at the 0.05 level. No statistically significant difference in the median total phosphorus concentrations was found at base flow between the pre- and post-BMP periods.

For both Brewery and Garfoot Creeks, the median storm loads for suspended sediment, total phosphorus, and ammonia nitrogen were compared statistically by means of the Wilcoxon rank-sum test. This test was also applied to the regression residuals for differences between the pre- and post-BMP periods. The regression represented the variability due to natural factors; a difference in the regression residuals could be attributed directly to a difference due to the BMPs.

For Brewery Creek, differences between the pre- and post-BMP median storm loads were not statistically significant at the 0.05 level for any of the three constituents described above. There was a decrease, however, in the regression residuals for ammonia nitrogen between the pre- and post-BMP periods that was statistically significant at the 0.05 level. This difference is likely attributed to the installed BMPs. For Garfoot Creek, only the median load for ammonia nitrogen showed a statistically significant difference between the pre- and post-BMP periods. Significant differences also were observed in the 
storm-load residuals for both total phosphorus and ammonia nitrogen. It appears that the implementation of BMPs in the Garfoot Creek watershed is improving the water quality of that stream. The reduction in the pre- and postBMP periods is likely due to the installed BMPs.

The overall results for the effectiveness of BMPs are mixed. In this study, the Garfoot Creek watershed showed more improvement in water quality than the Brewery Creek watershed. The Garfoot Creek watershed was fenced extensively, and most of the planned barnyard practices were installed. Fencing the stream corridor may have the greatest effect on constituent concentrations at base flow. Keeping animals out of the stream will allow banks to revegetate, and bank erosion will be reduced; stream-bottom sediments will not be resuspended, and animal waste will not be deposited directly in the stream. Fewer BMPs were installed in the Brewery Creek watershed, which may account for less improvement in water quality.

\section{References Cited}

American Public Health Association, 1985, Standard methods for the examination of water and wastewater 16th Edition: Washington, D.C., American Public Health Association, 1,268 p.

Cline, D.V., 1963, Hydrology of Upper Black Earth Creek basin: U.S. Geological Survey Water-Supply Paper 1669-C, 27 p.

Edwards, T.K., and Glysson, G.D., 1988, Field methods for measurement of fluvial sediment: U.S. Geological Survey Open-File Report 86-531, 118 p.

Field, S.J. and Graczyk D.J., 1990, Hydrology aquatic macrophytes, and water quality of Black Earth Creek and its tributaries, Dane County, Wisconsin, 1985-86: U.S. Geological Survey Water-Resources Investigations Report 89-4089, 38 p.

Gebert, W.A. and Krug, W.R., 1996, Streamflow trends in Wisconsin's driftless area: Journal of the American Water Resources Association, v. 32, no. 4, p. 733-744.

Glocker, C.L., and Patzer, R.A., 1978, Soil survey of Dane County: U.S. Department of Agriculture Soil Conservation Service, $193 \mathrm{p}$.

Guy, H.P., 1973, Laboratory theory and methods for sediment analysis: U.S. Geological Survey Techniques of Water-Resources Investigations, book 5, chap. C1, 58 p.
Helsel, D.R. and Hirsch, R.M., 1992, Statistical methods in water resources: New York, N.Y., Elsevier Science Publishing Company Inc., 522 p.

Holmstrom, B.K., Kammerer, P.A., Jr., and Erickson, R.M., 1986, Water resources data Wisconsin, water year 1985: U.S. Geological Survey Water Data-Report WI-85-1, 414 p.

Holmstrom, B.K., Kammerer, P.A., Jr., and Erickson, R.M., 1987, Water resources data Wisconsin, water year 1986: U.S. Geological Survey Water Data-Report WI-86-1, 402 p.

Holmstrom, B.K., Kammerer, P.A., Jr., and Erickson, R.M., 1991, Water resources data Wisconsin, water year 1990: U.S. Geological Survey Water Data-Report WI-90-1, 578 p.

Holmstrom, B.K., Kammerer, P.A., Jr., and Erickson, R.M., 1992, Water resources data Wisconsin, water year 1991: U.S. Geological Survey Water Data-Report WI-91-1, 607 p.

Holmstrom, B.K., Kammerer, P.A., Jr., and Ellefson, B.R., 1993, Water resources data Wisconsin, water year 1992: U.S. Geological Survey Water Data-Report WI-92-1, $545 \mathrm{p}$.

Holmstrom, B.K., Kammerer, P.A., Jr., and Ellefson, B.R., 1994, Water resources data Wisconsin, water year 1993: U.S. Geological Survey Water Data-Report WI-93-1, $707 \mathrm{p}$.

Holmstrom, B.K., Kammerer, P.A., Jr., and Ellefson, B.R., 1995, Water resources data Wisconsin, water year 1994: U.S. Geological Survey Water Data-Report WI-94-1, $645 \mathrm{p}$.

Holmstrom, B.K., Olson, D.L., and Ellefson, B.R., 1996, Water resources data Wisconsin, water year 1995: U.S. Geological Survey Water Data-Report WI-95-1, 562 p.

Holmstrom, B.K., Olson, D.L., and Ellefson, B.R., 1997, Water resources data Wisconsin, water year 1996: U.S. Geological Survey Water Data-Report WI-96-1, 464 p.

Holmstrom, B.K., Olson, D.L., and Ellefson, B.R., 1998, Water resources data Wisconsin, water year 1997: U.S. Geological Survey Water Data-Report WI-97-1, 506 p.

Holmstrom, B.K., Olson, D.L., and Ellefson, B.R., 1999, Water resources data Wisconsin, water year 1998: U.S. Geological Survey Water Data-Report WI-98-1, 508 p.

Interagency Advisory Committee on Water Data, 1982, Guidelines for determining flood-flow frequency: Bulletin 17B of the Hydrology Subcommittee, Office of Water Data Coordination: Reston, Va., U.S. Geological Survey, 183 p. 
Krohelski, J.T., Lin Yu-Feng, Rose, W.J. and Hunt, R.J., 2002, Simulation of Fish, Mud, and Crystal Lakes and the shallow ground-water system, Dane County, Wisconsin: U.S. Geological Survey Water-Resources Investigations Report 02-4014, 17 p.

MathSoft, 2000, S-Plus 200, Users Guide to Statistics: Data analysis products 1ts Division, MathSoft: Seattle, Wash., 638 p.

National Oceanic and Atmospheric Administration, Climatological data annual summary, 2000, Wisconsin, v. 105, no. $13,27 \mathrm{p}$.

Porterfield, G., 1972, Computation of fluvial-sediment discharge: U.S. Geological Survey Techniques of WaterResources Investigations, book 3, chap. C2, 66 p.

Rantz S.E., and others, 1982, Measurement and computation of Streamflow-v. 2, Computation of discharge: U.S. Geological Survey Water-Supply Paper 2175, p. 285-631.

Rappold, K.F., Wierl, J.A., and Amerson, F.U., 1997, Watershed characteristics and land management in the nonpoint source evaluation monitoring watershed in Wisconsin: U.S. Geological Survey Open-File Report 97-119, 39 p.

University of Wisconsin-Extension, 1998, A guide to environmentally sound practices for Wisconsin farmers: Univeristy of Wisconsin-Extension UXEW Publication GWQ025, 31 p.

Walker, J.F., 1993, Techniques for detecting effects of bestmanagement practices on stream-water chemistry: U.S. Geological Survey Open-File Report 93-130, 16 p.

White K.E. and Sloto R.A., 1990, Base-flow frequency characteristics of selected Pennsylvania streams: U.S. Geological Survey Water-Resources Investigations Report 90-4160, 67 p.

Wierl, J.A., Rappold, K.F., and Amerson, F.U., 1996, Summary of the land-use inventory for the nonpoint-source evaluation monitoring watershed in Wisconsin: U.S. Geological Survey Open-File Report 96-123, 23 p.

Wischmeier, W.H., and Smith, D.D., 1978, Predicting rainfall erosion losses-a guide to conservation planning: U.S. Department of Agriculture Handbook, no. $537,58 \mathrm{p}$.

Wisconsin Department of Natural Resources, 1989, A plan for control of nonpoint sources and related resource management in the Black Earth Creek priority watershed: Wisconsin Department of Natural Resources Publication WR-218-89 [variously paged].
Wisconsin Laboratory of Hygiene, 1992, Manual of analytical methods and quality assurance: Madison, Wisconsin, University of Wisconsin, 330 p.

Viesman, W.H., Knapp, J.W., Lewis, G.L. and Harbaugh, T.E., 1977, Introduction to hydrology, (2d ed): New York, Harper \& Row Publishers Inc., 704 p. 